\title{
Modeling Services Liberalization: The Case of Tanzania
}

\author{
by \\ Jesper Jensen, Teca Training, Denmark \\ Thomas F. Rutherford, Swiss Federal Institute of Technology (ETH-Zurich) \\ and \\ David G. Tarr, The World Bank
}

April 30, 2008

\begin{abstract}
This paper employs a 52 sector small open economy computable general equilibrium model of the Tanzanian economy to assess the impact of the liberalization of regulatory barriers against foreign and domestic business service providers in Tanzania. The model incorporates productivity effects in both goods and services markets endogenously, through a Dixit-Stiglitz framework. It summarizes policy notes on the key business services sectors that were prepared for this work, and estimates the ad valorem equivalent of barriers to foreign direct investment based on these policy notes and detailed questionnaires completed by specialists in Tanzania. The authors estimate that Tanzania will gain about 5.3 percent of the value of Tanzanian consumption in the medium run (or about 4.8 percent of gross domestic product) from a full reform package that also includes uniform tariffs. The estimated gains increase to about 16 percent of consumption in the long-run steady-state model, where the impact on the accumulation of capital from an improvement in the productivity of capital is taken into account. Decomposition exercises reveal that the largest gains to Tanzania will derive from liberalization of costly regulatory barriers that are non-discriminatory in their impacts between Tanzanian and multinational service providers.
\end{abstract}

Corresponding author:

David Tarr

MSN 3-303

The World Bank

1818 H. St. NW, Washington DC 20433

telephone: (1-202) 473-7677

fax (1-202) 522-1159

Email DTARR@Worldbank.org

We thank Bobbie Mircheva and Cyril Pesha for help with the data and estimates of parameters in this paper. We thank Josaphat Kweka, Jan Erik Von Uexkull, Paul Brenton, Robin Carruthers, Paulo Zacchia, Peter Silarszky, Dr. John Nkoma, Christopher Juan Costain, and Craig Thorburn for helpful comments, conversations or provision of data. Financial support from the Bank-Netherlands Partnership Program under the Services in Africa project is gratefully acknowledged. The views expressed are those of the authors and do not necessarily reflect those of the World Bank, its Executive Directors, the Government of Tanzania or those acknowledged. 


\title{
Modeling Services Liberalization: The Case of Tanzania
}

\author{
by \\ Jesper Jensen, Teca Training, Denmark \\ Thomas F. Rutherford, Swiss Federal Institute of Technology (ETH-Zurich) \\ and \\ David G. Tarr, The World Bank
}

\section{Introduction}

Both economic theory and empirical literature have shown that wide availability of business services results in productivity gains to the manufacturing sector and contributes to its international competitiveness. ${ }^{1}$ In many of the services sectors in Tanzania, however, the regulatory regime imposes significant burdens on the cost of providing services, both by Tanzanian service providers and by multinationals. Consequently, the number of service providers and their quality is lower than it could be. Reform of the regulatory regimes in Tanzanian services sectors could therefore result in an increase in the number of providers and the quality of business service provision in Tanzania.

\footnotetext{
${ }^{1}$ Marshall (1988) shows that in three regions in the United Kingdom (Birmingham, Leeds and Manchester) almost 80 percent of the services purchased by manufacturers were bought from suppliers within the same region. He cites studies which show that firm performance is enhanced by the local availability of producer services. In developing countries, McKee (1988) argues that the local availability of producer services is very important for the development of leading industrial sectors.

Both the urban economics literature (Vernon, 1960; Chinitz, 1961) and the more recent economic geography literature (e.g., Krugman, 1991; Porter, 1992; Fujita, Krugman and Venables, 1999) has focused on the fact that related economic activity is economically concentrated due to agglomeration externalities (e.g., computer businesses in Silicon Valley, ceramic tiles in Sassuolo, Italy). Evidence comes from a variety of sources. Ciccone and Hall (1996) show that firms operating in economically dense areas are more productive than firms operating in relative isolation. Caballero and Lyons (1992) show that productivity increases in industries when output of its input supplying industries increases. Hummels (1995) shows that most of the richest countries in the world are clustered in relatively small regions of Europe, North America and East Asia, while the poor countries are spread around the rest of the world. He argues this is partly explained by transportation costs for inputs since it is more expensive to buy specialized inputs in countries that are far away for the countries where a large variety of such inputs are located.
} 
Moreover, Tanzania is involved in negotiations of commitments in services in various regional arrangements, such as the European Partnership Agreements, COMESA ${ }^{2}$ and the East African Customs Union. ${ }^{3}$ And in the context of its international negotiations under the Doha Development Agenda, Tanzania may be called upon to make further commitments in the business services area. We shall argue that while there are barriers against foreign investment in business services, in practice, the more significant regulatory barriers in Tanzanian raise the costs of providing business services in a nondiscriminatory manner. Moreover, Tanzanian commitments at the WTO or in its regional arrangements are considerably less open than its practice. Binding commitments made at the WTO or in regional agreements provide a signal to investors in the services sectors that they are welcome and that the regulatory regime will not be turned against them arbitrarily.

What would be the consequences for Tanzania of responding to the requests of its trading partners by agreeing to further commitments? How much would Tanzania gain from reform of its regulatory regime if reform could reduce the costs of providing business services by both its domestic firms as well as multinationals? What would be the impact on industry, agriculture, wages, returns to capital, exports and imports, as well as the services sectors themselves from reforms in the services sectors?

In this paper we develop a 52 sector small open economy comparative static computable general equilibrium model of Tanzania that we believe is appropriate to evaluate the impact of Tanzanian liberalization of services barriers. We adopt the Dixit-Stiglitz-Ethier structure for business services (and for increasing returns to scale goods) that implies endogenous productivity gains from the net introduction of new varieties of service providers or from additional varieties of imperfectly competitive goods. ${ }^{4}$ Key to our model is that we allow foreign direct investment in business services and assume that

\footnotetext{
${ }^{2}$ The Common Market for Eastern and Southern Africa (COMESA) is a preferential trade area among Djibouti, Tanzania, Madagascar, Malawi, Mauritius, Sudan, Zambia and Zimbabwe.

3 The East African Customs Union is a customs union among Tanzania, Uganda and Tanzania.

${ }^{4}$ Elasticities of substitution for product categories in the Dixit-Stiglitz framework have been estimated by Broda and Weinstein (2004). They estimate that, although there are variances within the groups, for agriculture, services and
} 
a domestic presence is required in business services in order for multinational service providers to compete effectively with domestic service providers.

We have commissioned policy notes on the key business services sectors in Tanzania. In this paper, we summarize the key problems and regulatory reforms in the telecommunications, insurance, banking, and several transportation sectors. We believe that the description of these sectors and the issues is of interest independent of the modeling. But we use these policy notes to inform the modeling.

Crucial to our analysis, we estimate the ad valorem equivalents of the regulatory barriers in business services in Tanzania, both discriminatory against foreign investors as well as non-discriminatory barriers that apply to domestic and multinational service providers. Among our business services sectors, we find that the regulatory costs are the highest in the transportation sector (especially the maritime sector). Although the regulatory costs are higher for foreign firms, they are very high for domestic firms as well. Regulatory barriers in the banking and insurance sectors are also quite significant.

We find that the Tanzanian tariff structure on average is not very high. On the other hand, there is high dispersion in the tariff structure with some sectors, like sugarcane, beverages and tobacco, textiles and leather products, beans, cassava, meat and dairy products, fish and sugar, with rather high tariffs. Consequently, we also evaluate the potential gains to the Tanzanian economy and the impact on different sectors of moving to a uniform tariff.

In our "full reform" package, we estimate that Tanzania will gain 11.4 percent of consumption or 9.6 percent of GDP per year. We argue that the gains to Tanzania derive from three principal effects: (1) the largest gains derive from a reduction in regulatory barriers against service providers. This will increase the number of service varieties available in Tanzania. The variety increase will increase total factor productivity (or lower the quality adjusted costs) in sectors that use business services. Due to their larger share of the market, there are greater gains from liberalization of the regulatory barriers against domestic service providers than from liberalization against foreign service providers; (2) tariff uniformity

goods the Dixit-Stiglitz elasticitiy of substitution is close to three. We choose three as our central Dixit-Stiglitz elasticity of substitution. 
alone induces gains of 0.7 percent of GDP per year. The reason is that the distortion costs of a tariff increase with the square on the tariff. Then moving to uniformity can be expected to benefit the country since it is the very high tariffs that cause the most of distortion costs; and (3) positive effects on the accumulation of capital from an increase in the productivity of capital due to better access to services will result in an increase in the capital stock in the long run. We use our comparative steady state model to assess that the gains to the economy, when the positive impact on the long run capital stock is taken into account. The estimated gains increase to 77 percent of consumption or 65 percent of GDP per year. In the long run, we estimate a generalized expansion of the output of the manufacturing sector, both the competitive and the imperfectly competitive parts.

This paper builds on the work of Markusen, Rutherford and Tarr (2005), Jensen, Rutherford and Tarr (2007) and Balistreri, Rutherford and Tarr (2008). Markusen, Rutherford and Tarr developed a stylized model where foreign direct investment is required for entry of new multinational competitors in services, but they did not apply this model to the data of an actual economy. The paper by Jensen, Rutherford and Tarr (2007) on Russian WTO accession examined the impact of liberalization of barriers against foreign direct investment in business services, but did not evaluate the impact of liberalization of domestic regulatory barriers. The paper by Balistreri, Rutherford and Tarr (2008) in Kenya is closest to this model, but tourism is a crucial sector in Tanzania and there are several key issues in the treatment of tourist revenues that are crucial to the results in Tanzania that did not arise in the Kenya model.

The paper is organized as follows. In section II we summarize the policy notes that we have prepared for this project in the key business services sectors. In section III, we explain the estimation of the ad valorem equivalents of the regulatory barriers. In section IV, we describe the model and the most important data. In section $\mathrm{V}$ we describe and interpret the central policy scenarios and discuss the sensitivity analysis. We conclude briefly in section VI.

\section{Overview of the Tanzanian Services Sectors}


In this section, we summarize the key institutional and policy issues in telecommunications, banking, insurance and transportation. This discussion is based on several policy notes written in 2008 on the Tanzanian business services sectors, namely Tarr (2008), Carruthers (2008), Thorburn (2008) and Costain (2008).

\section{Telecommunications.}

The government has implemented significant reforms in the sector since the reform program began in 1993. Fixed line telephone services failed to provide significant access. As of September 2007, there were only 161 thousand fixed lines available in Tanzania. With a population of almost 38 million, less than one percent of the population had its own fixed line fixed line telephone. However, the mobile telephone service network has been rapidly expanding so that there were over 7.5 million mobile telephone service subscribers as of end 2007 who were receiving service at very competitive prices.

The Tanzanian telecommunications regulatory environment is based on the modern "converged" licensing framework, and is not restrictive regarding entry requirements. The non-restrictive regulatory environment has introduced competition in the telecommunications sector, and should be credited with much of the success of the mobile telephone build-out. Nonetheless significant problems remain in the telecommunications sector. Notably: (i) there is a need to develop the Information and Communication Technology (ICT) network efficiently; (ii) internet and data transmission services are very costly; (iii) electronic commerce is seriously constrained by the need to develop credit reference bureaus, the lack of a national payments system, and a legislative framework appropriate for e-business; and (iv) there is a need to make progress in achieving universal service. We now discuss the former two problems in more detail.

Internet Service Provision and Data Transmission. Internet service provision and data transmission are very expensive in Tanzania. The Telecommunications Management Group (2007) report notes that in 2004 a monthly basket of internet access services costs US $\$ 117$, whereas the same basket costs an average of US\$ 54.8 in sub-Saharan Africa and an average of US\$45.5 in low income countries. The primary explanation for the high cost of these services is that East Africa is the only major coastline 
in the world without access to a fiber-optic cable network. In early 2008, these services are provided by satellite services, which are more expensive than fiber optic seabed cable. Completion of either or both of the two cable systems under construction (the EASSy cable or the SEACOM system) should lower the costs of internet and data transmission services. A reduction in the costs of internet transmission services will likely result in more internet service users. More internet users will likely allow achievement of economies of scale in production that would further reduce costs.

\section{National Information and Communication Technologies (ICT) Backbone Network in}

Tanzania. The limited geographical coverage of the national ICT backbone network is a key constraint on the development of the ICT sector in Tanzania. A preliminary feasibility study of the national ICT backbone network, conducted by Swedtel during the second half of 2006, estimates the cost of constructing the national ICT backbone network in the range of $\$ 75-\$ 100$ million. The study also identified opportunities for reducing the necessary amount of public funding for the implementation of the backbone network by utilizing Public-Private Partnerships.

Nonetheless, the Government of Tanzania, through the then Ministry of Infrastructure Development (MoID) (and now the Ministry of Communications, Science and Technology) has been considering a project to implement a national ICT backbone network at a much higher cost of $\$ 170$ million with the support of a loan from the Government of China arranged with the help of China International Telecommunications Construction Corporation (CITCC). Moreover, implementation of the CITCC proposal would require an exception from the national procurement law due to sole sourcing and a conflict of interest - the same company (CITCC) developed the cost estimates and later was selected (without any competitive process) to implement the network. The potential higher cost of the National ICT Backbone is likely to result into higher end-user prices. Competitive ICT prices would be better served if the Government of Tanzania were to: (i) use the the private sector, wherever possible; (ii) procure the network competitively; and (iii) establish the network in a way which promotes competition.

\section{Transportation}


The Port of Dar es Salaam. As of early 2008, there were widespread complaints about the container terminal at Dar es Salaam. Congestion in the container terminal of the port is the greatest transport impediment to an increase in exports. The container terminal was concessioned to TICTS in 2000, when the throughput was less than 100,000 tons of equivalent units (TEU). By offering a high quality service, the terminal was able to attract much of the traffic of the land-locked countries for which it is convenient transit port as well as for the rapidly growing Tanzanian economy.

As the throughput approached and passed the nominal capacity of 250,000 TEU and is approaching 350,000 in 2008, the number of containers loaded or offloaded per hour fell to less than half of what was achieved in 2004 and 2005, at the peak of the port's efficiency. The average waiting time for ships to access a container berth is twelve days, while the average total time for a ship in the port ("dwell time") is approaching 30 days. This congestion is raising costs for both importers and exporters and undermining firms that rely on speed and reliability to market. As a result, some shipping lines are reducing the frequency of calls to the port.

There are two main inter-related causes of this drop in efficiency: (i) poor management of containers in the port; and (ii) the terms of the concession contract provide perverse incentives to the container terminal operator. That is, the operator has an incentive to maximize the number of containers in the terminal; the contract lacks any performance targets for the operator; and the contract discourages the operator from sustained increases in throughput.

Carruthers (2008) outlines numerous short term, medium term and long term measures that can be taken to relieve the congestion problem. Some measures require investment. But review of the contract with TICTS, to replace perverse incentives with incentives for efficiency, is clearly one of the most important. 
Roads and Border Crossings. Caruthers reports that the roads are of poor quality and that there are many small inefficient companies operating. Border crossings within the East African Customs Union (EAC) are characterized by poor infrastructure and facilities, which typically results in long transit delays, poor traffic management, traffic jams and congestion at crossing points and parking yards. Delays of several days are reported when the ferry from Tanzania arrives in the Democratic Republic of Congo (DRC) and in Tanzania for the reverse journey. Similar delays occur at the border with Zambia. Anecdotal evidence from newspaper reports suggests that truck delays at the border between Tanzania and Kenya often lead to damage to flowers being transported for onward air freight from Nairobi. Clearly there are opportunities for improvements to transit arrangements.

EAC authorities have agreed to move towards the implementation of One-Stop Border Posts, which are expected to reduce transit time at the borders. Nine border posts have been selected for transformation. Of these, four are between Tanzania and Kenya and one each between Tanzania and Rwanda and Uganda.

Railroads. Due to a lack of investment, Tanzania's railways have significantly declined and are considered rather poor providers of freight transportation services since the $1980 \mathrm{~s}^{5}$ The Tanzania Railways Corporation, ${ }^{6}$ in the hope of improved performance, gave RITES, an Indian company, a concession to exclusively operate its routes and invest in the railroads. As of the end of 2007, the RITES concession had only been in operation for several months, and was still in the process of rebuilding its track infrastructure and acquiring refurbished and rebuilt locomotives and wagons from India.

Airlines There is a lack of capacity to handle significant freight shipping. Due to lack of capacity in air freight facilities in Dar es Salaam, many Tanzanian cut flower producers choose to ship flowers by land to Nairobi, despite the high costs of border delays. .

\section{Banking}

Banking sector reform in Tanzania started in the early 1990's and has continued to the present. A new regulatory framework has been introduced and new banks have entered the market so that there were 
25 banks operating in Tanzania in 2007, including Tanzanian, banks from within the region (notably South Africa but also Kenya, Botswana and Uganda), from OECD countries and from Asia (India, Pakistan and Malaysia). Banking supervision in Tanzania complies with many of the "Basel Core Principles."

The banking sector, however, performs only a very limited role in the economy, even by SubSaharan African standards. Private sector credit remains limited, short term interest rate spreads are high, banks continue to invest approximately half their deposits in Government securities (although loan to deposit ratios have improved in recent years), banks continue to maintain significant offshore foreign currency deposits (about 39\% of total deposits as of October 2007). Housing finance is negligible as residential mortgages represent less than $1 \%$ of all bank loans.

The overall market environment appears to have benefited from increased competition and private sector credit has increased significantly while interest rate spreads are estimated to have declined from $11 \%$ at December 2005 to about 8.6\% as at end of December 2006. The move to sell off a controlling stake in National Microfinance Bank (NMB) to a foreign strategic investor with strong experience in rural credit appears to have paid off through an introduction of innovative new products and approaches to agricultural finance and microfinance.

Besides crop finance, banks and microfinance institutions have made limited headway in finding secure and cost-effective ways of lending for agricultural finance. In order to develop new business models and lending technologies, the key task for Government will be ensuring the legal and information infrastructures for banks and other financial institutions are in place. The general credit culture and institutional framework for contract enforcement remains underdeveloped and this has inhibited the growth of financial markets. The almost total absence of a mortgage market is a reflection of both the uncertainty concerning land title and the inability to enforce a contract.

Foreign banks, particularly the new entrants, have been challenged in mobilizing local currency for lending to match both their capital and institutional capacity. A better-developed interbank market would serve to extend the provision of credit within the domestic financial system. In 2008, shilling deposits were held largely by the three large domestic banks.

The efficient operation of the financial markets can be much assisted through the effective use of registries such as a land registry, company registry and a movable collateral registry. In addition, banks in particular are supported in their lending activities through the use of credit information bureaus. While these registries exist in Tanzania, their usefulness has been impeded by relatively weak implementation (and, in the case of the credit bureau, limited cooperation from the larger banks).

\footnotetext{
${ }^{6}$ The Tanzania Railways Corporation offers service within Tanzania and on to the Democratic Republic of Congo, Burundi and Rwanda. TANZARA offers service between Tanzania and Zambia.
} 
Although the Bank of Tanzania has substantial operating independence on banking supervision matters, some features of the legislation have the potential to compromise its independence. At the same time, despite substantial progress, it would be useful to further increase transparency and accountability in the banking supervision procedures of the Bank of Tanzania, as well as the development of a risk based approach to banking supervision.

\section{Insurance.}

Although the structure of the non-life insurance market is competitive (but not the life insurance market), the insurance sector is not well developed. Current regulations impede the growth of the sector. These rules include restricting foreign ownership to two-thirds of capital, requiring insurers to be locally incorporated entities, not allowing foreign branches or wholly owned subsidiaries of foreign insurers, not allowing cooperative and mutual insurance companies and limits that make it less attractive for banks to participate in the distribution of insurance.

There are no foreign reinsurance companies operating in Tanzania. This is partly due to the fact that reinsurance arrangements have, at their core, compulsory reinsurance requirements to TanRe, a company indirectly owned by the government. Moreover, reinsurance companies are prohibited to operate as either branches or as wholly owned subsidiaries of foreign domiciled reinsurers. Reinsuring externally, and insuring for that matter, also requires approval.

\section{Professional services.}

Reports from the Kenya are that its nationals have limited rights to provide professional services in Tanzania. The principal barriers is this sector are discriminatory.

\section{Estimation of the Tariff Equivalence of the Regulatory Barriers}

Estimates of the ad valorem equivalents of the regulatory barriers in services are key to the results. In order to make these estimates, we first need to assess the regulatory environment in the services sectors in our model. We commissioned a 54 page survey of the regulatory regimes in key Tanzanian business services sectors, namely, insurance, banking, fixed line and mobile telecommunications services 
and maritime transportation services. ${ }^{7}$ We supplemented this information based on the policy notes discussed in section II. The Telecommunications Management Group (2007) provided extensive details in telecoms. These questionnaires and papers provided us with data and descriptions and assessments of the regulatory environment in these sectors.

Mircheva (2008) then estimated the ad valorem equivalents of barriers to foreign direct investment in fixed line and mobile telecommunications, banking, insurance and maritime transportation services. The process involved converting the answers and data of the questionnaires into an index of restrictiveness in each industry. Mircheva followed the methodology of Kimura, Ando and Fujii (2004a, $2004 b, 2004 c)$ to generate these estimates. The methodology involves classification of the possible restrictions into separate categories with unique weights summing to one, where the weights are determined based on the significance of each category. Next, Mircheva assigned a score to each potential restriction, where the score reflects the level of restriction imposed by the economy. Mircheva estimated two indices: an index of "regulatory barriers" (RB index) where the regulatory barriers impose costs on both domestic and multinational firms in a non-discriminatory manner; and an index of discriminatory barriers against multinational service providers, which we call the foreign discriminatory index (FDR index). ${ }^{8}$

This methodology further involves building on the estimates and methodology explained in the volume by C. Findlay and T. Warren (2000), notably papers by Warren (2000), McGuire and Schulele (2000) and Kang (2000). For each of these service sectors, authors in the Findlay and Warren volume evaluated the regulatory environment across many countries. The price of services is then regressed against the regulatory barriers to determine the impact of any of the regulatory barriers on the price of services. Mircheva then assumed that the international regression applies to Tanzania in the case that the above mentioned restrictiveness indexes are used. Applying that regression and their assessments of the regulatory environment in Tanzania from the questionnaires and other information sources, she estimated the ad valorem impact of a reduction in barriers ${ }^{9}$ both for discriminatory and non-discriminatory barriers. Mircheva then weighted her fixed line and mobile telecommunications estimates by their market shares to obtain her estimate for communications. The results of the estimates are listed in table 4 .

\section{Overview of the Model and Key Data}

\footnotetext{
${ }^{7}$ We thank Mr. Cyril Pesha and his law firm associates in Dar es Salaam for leading this research effort.

${ }^{8}$ In order to obtain the estimated score for each restriction, the assigned score is multiplied by the corresponding weight. Finally, the estimated scores for all categories are summed to obtain the restrictiveness indices.

$9 \quad$ Warren estimated quantity impacts and then using elasticity estimates was able to obtain price impacts. The estimates by Mircheva that we employ are for "discriminatory" barriers against foreign direct investment.
} 


\section{Overview of the Model Formulation}

This paper follows the algebraic structure of the model of Jensen, Rutherford and Tarr (2007). Here we provide a general description. There are 52 sectors in the model shown in table 1 . These include eight imperfectly competitive business services sectors, eleven imperfectly competitive manufacturing sectors, nineteen competitive agricultural sectors and fourteen competitive manufacturing or services sectors. Primary factors include 8 types of labor grouped both according to gender and to one of four levels of education; child labor; agricultural land; mobile capital; sector-specific capital in imperfectly competitive sectors; and primary inputs imported by multinational service providers, reflecting specialized management expertise or technology of the firm. The existence of sector specific capital in several sectors implies that there are decreasing returns to scale in the use of the mobile factors and supply curves in these sectors slope up. In our central model, we assume that 50 percent of the capital in each of the imperfectly competitive sectors in sector specific. We conduct sensitivity analysis with respect to this share by allowing 25 percent and 75 percent of the capital in each sector to be sector specific.

Regardless of sector, all firms minimize the cost of production. One category of sectors is competitive goods and services sectors produced under constant returns to scale and where price equals marginal costs with zero profits. This includes all 19 of the agriculture sectors, some food processing sectors such as meat and dairy products and grain milling, and services such as construction, hotels and restaurants, postal communication, real estate, public administration, health and education. In these sectors, products are differentiated by country of origin, i.e., we employ the Armington assumption. All goods producing firms (including imperfectly competitive firms) can sell on the domestic market or export. Firms optimize their output decision between exports and domestic sales based on relative prices and their constant elasticity of transformation production function.

Tourism is one of the sectors in this category, and given its importance in the Tanzanian economy, it deserves its own discussion. All sales to tourists are considered exports, i.e., the sector does 
not produce for the domestic market. Based on a survey (discussed below), we have that the inputs of the sector are domestic transportation services, hotel and restaurant services, clothing, gold items, and certain food products, as well as foreign inputs such as international travel expenditures. Given that we have data only on tourist expenditure by sector and on tourism imports and exports, we assume that the output of this sector is produced without value added. But the tourism sector demands domestically produced services and goods that lead to value-added in the Tanzanian economy. Moreover, the sector is intensive in services and this way we capture the impacts on services liberalization on services exports. We discuss the special data issues related to this sector in the data section below.

Goods produced subject to increasing returns to scale are differentiated at the firm level. We assume that manufactured goods may be produced domestically or imported. Firms in these industries set prices such that marginal cost (which is constant) equals marginal revenue; and there is free entry, which drives profits to zero. For domestic firms, costs are defined by observed primary factor and intermediate inputs to that sector in the base year data. Foreigners produce the goods abroad at constant marginal cost but incur a fixed cost of operating in Tanzania. The cif import price of foreign goods is simply defined by the import price, and, by the zero profits assumption, in equilibrium the import price must cover fixed and marginal costs of foreign firms. We employ the standard Chamberlinian large group monopolistic competition assumption within a Dixit-Stiglitz framework, which results in constant markups over marginal cost.

For simplicity we assume that the composition of fixed and marginal cost is identical in all firms producing under increasing returns to scale (in both goods and services). This assumption in a our DixitStiglitz based Chamberlinian large-group model assures that output per firm for all firm types remains constant, i.e., the model does not produce rationalization gains or losses.

The number of varieties affects the productivity of the use of imperfectly competitive goods based on the standard Dixit-Stiglitz formulation. The effective cost function for users of goods produced subject to increasing returns to scale declines in the total number of firms in the industry. 
The third category of sectors is services sectors that are produced under increasing returns to scale and imperfect competition, namely telecommunications, financial services, transportation services and professional business services. In services sectors, we observe that some services are provided by foreign service providers on a cross border basis analogous to goods providers from abroad. But a large share of business services are provided by service providers with a domestic presence, both multinational and Tanzanian. ${ }^{10}$ Our model allows for both types of foreign service provision in these sectors. There are cross border services allowed in this sector and they are provided from abroad at constant costs - this is analogous to competitive provision of goods from abroad. Cross border services, however, are not good substitutes for service providers who have a domestic presence. ${ }^{11}$

There are also multinational service firm providers that choose to establish a presence in Tanzania in order to compete with Tanzanian firms directly. When multinationals service providers decide to establish a domestic presence in Tanzania, they will import some of their technology or management expertise. That is, foreign direct investment generally entails importing specialized foreign inputs. Thus, the cost structure of multinationals differs from national only service providers. Multinationals incur costs related to both imported primary inputs and Tanzanian primary factors, in addition to intermediate factor inputs. Foreign provision of services differs from foreign provision of goods, since the service providers use Tanzanian primary inputs. Domestic service providers do not import the specialized primary factors available to the multinationals. Hence, domestic service firms incur primary factor costs related to Tanzanian labor and capital only. These services are characterized by firm-level product differentiation. For multinational firms, the barriers to foreign direct investment affect their profitability and entry. Reduction in the constraints on foreign direct investment will induce foreign entry that will typically lead

\footnotetext{
${ }^{10}$ One estimate puts the world-wide cross-border share of trade in services at $41 \%$ and the share of trade in services provided by multinational affiliates at $38 \%$. Travel expenditures $20 \%$ and compensation to employees working abroad $1 \%$ make up the difference. See Brown and Stern (2001, table 1).

${ }^{11}$ Daniels (1985) found that service providers charge higher prices when the service is provided at a distance.
} 
to productivity gains because when more varieties of service providers are available, buyers can obtain varieties that more closely fit their demands and needs (the Dixit-Stiglitz variety effect).

Comparative Steady State Formulation. In this version of our model, we allow the capital stock to adjust to its steady state equilibrium along with all of the model features we employ in our central scenario, i.e., we allow for tariff and FDI liberalization with endogenous productivity effects as above. The increased availability of services results in an endogenous increase in productivity and an increase in the marginal productivity of capital in particular. An increase in the marginal productivity of capital should increase the accumulation of capital and, in the long run steady state, increase the capital stock. In this scenario the impact on the accumulation of capital from an improvement in the productivity of capital is taken into account. We call this our comparative steady state model.

In the comparative static model, we assume that the capital stock is fixed and the rental rate on capital is endogenously determined. In the comparative steady state model, the logic is reversed. We assume that the capital stock is in its initial steady state equilibrium in the benchmark dataset, but that the capital stock will adjust to a new steady state equilibrium based on a fixed rate of return demanded by investors. That is, if the trade policy shock happens to induce an increase in the rate of return on capital so that it exceeds the initial rate of return, investors will invest and expand the capital stock. Expansion of the capital stock drives down the marginal product of capital, i.e., it drives down the rental rate on capital, until the rate of return on capital falls back to the initial level. ${ }^{12}$ To analyze trade policy, this comparative steady state approach has been employed by many authors, including Harrison, Rutherford and Tarr (1996, 1997) and Baldwin et al. (1999) and Francois et al. (1996). The approach, however, dates back to the 1970s, when both Hansen and Koopmans (1972) and Dantzig and Manne (1974) used it. The approach ignores the foregone consumption necessary to achieve the higher level of investment and thus, is an upper bound estimate on the long run gains within the framework of the model assumptions.

\footnotetext{
${ }^{12}$ The rate of return on investment in our model is the rental rate on capital divided by the cost of a unit of the capital good.
} 


\section{Data}

The core of the model data is the Social Accounting Matrix (SAM) for 2001 developed by Thurlow and Wobst (2003). The SAM contains 43 sectors, most of which are agricultural and foodproducing sectors and only a few are service sectors.

Two sectors in the SAM, "Transport and communication" and "Business and other service activities", account for most business services in Tanzania. Given our focus on services, these sectors are disaggregated into 10 sectors using unpublished national accounts data for the year 2006 from the National Bureau of Statistics of Tanzania.

Data for gross domestic product for the sectors "Transport", "Communications", "Financial intermediation", and "Real estate and business services" is officially published (National Bureau of Statistics (2007)). Upon specific request, we received a breakdown of these data for the main types of services within each sector. Specifically, the data allows us to disaggregate "Transport and communication" into road transport, railway transport, water transport, air transport, postal services and telecommunication. "Business and other service activities" is disaggregated into insurance, banking, business services and other services.

Within each of the two aggregate sectors, the share of gross domestic product by disaggregate sector is used to decompose the corresponding aggregate sector. It is furthermore assumed that the input output structure for all the disaggregate sectors is identical to the input output structure of the corresponding aggregate sector. Along with the addition of the tourism sector, the resulting table has 52 sectors as shown in table 1 .

The SAM includes 12 household accounts. 6 accounts represent rural households and 6 accounts represent urban households. 2 accounts in each group represent households below the food poverty line and between the food and basic needs poverty lines. The other accounts are grouped according to the education of the head of the household. ${ }^{13}$

\footnotetext{
${ }^{13}$ Average per capita income in the SAM is calculated as USD 2.2 per day. This calculation is based on income data in the SAM, the number of heads in each of the household accounts as reported by Thurlow and Wobst (2003), and a purchasing power parity conversion between Tanzanian Schillings and USD of 274.16 (see Heston et al. (2006)). The market exchange rate for 2001 reported by the Bank of Tanzania is 876.4 Tanzanian Schillings per USD.
} 
The SAM contains nine types of labor: Adults are grouped both according to gender and to one of four levels of education. All child labor (age 10 to 14) is the 9th and final category. Capital and agricultural land and a factor called a subsistence factor are the three remaining primary factors of production.

The subsistence factor is a composite of land, labor and capital used in the production for home (own) consumption by households. ${ }^{14}$ The subsistence factor is used in the agricultural and foodproducing sectors. In each sector the SAM shows the value of output allocated for home consumption and of output allocated to the market, both of which are coming from the same activity.

Tariff Data. We were fortunate to receive unusually detailed collected tariff data from the Tanzania Revenue Authority. That is, we received data on collected import duties (tariffs) and import values at the eight digit tariff line level. The collected tariff rates for the sectors in our model are obtained by first aggregating the eight digit tariff line level tariff collections and import values to the sectors of our model. The ratio of tariff collections to import values for each sector of our model is then calculated to give estimates of the collected tariff rates, which in turn are incorporated into our SAM. The tariff rates are shown in Table 4. Applying these tariff rates across all sectors implies that tariff revenue in the revised database is about $1.3 \%$ of GDP, which is consistent with collected revenues in Tanzania. ${ }^{15}$ The SAM has some detail on taxes, which include direct taxes on households and enterprises, import tariffs, producer taxes, indirect (sales) taxes and factor taxes. The data for import tariffs are replaced with collected tariff rate data for the year 2006.

The Thurlow and Wobst SAM allocates international travel expenditure (mainly international tourism) to the "Transport and communication" sector. According to a survey conducted by the Bank of Tanzania (2007), this is grossly contradicted by the facts. Given our focus on services and the importance of tourism to the Tanzanian economy, we had to correct this problem.

In our first step, we reduced imports and exports in the "Transport and communication" sector by the value of tourism imports and tourism exports, respectively. This yields levels of traditional exports

\footnotetext{
${ }^{14}$ Data do not allow a breakdown of the subsistence factor on its shares of the other primary factors.

${ }^{15}$ For the year 2006, aggregate data from Tanzania show that tariff collections are 1.47 percent of GDP.
} 
and imports for this sector which are roughly in line with balance of payments data from the Bank of Tanzania for these sectors.

In the second step, we had to reallocate the tourist expenditures subtracted from Transportation and Communication to other sectors. Since most of the tourism imports are re-exported, e.g., international air travel, we chose to calculate net tourism expenditures. We allocated the the net expenditures to the various sectors of our model based on the Bank of Tanzania survey results.

The survey revealed that around $28 \%$ of total expenditure of non-package tourists is transport, $29 \%$ is accommodation, $12 \%$ is shopping and $31 \%$ is other expenditure. We therefore allocated the tourism expenditures to the following sectors: $29 \%$ to "Hotels \& restaurants," $28 \%$ to road transport, railway transport and air transport in proportion to the three sectors' contribution to GDP. The remaining $43 \%$ is on goods. We allocate these expenditures to the goods producing sectors in proportion to their share in total exports of goods. Major examples of tourist expenditure on goods include clothing, gold items, and food products such as cashew nuts and coffee.

This allocation of tourist expenditures implies that our SAM gets additional accounts representing "Tourism". An activity account (the tourism sector) contains the tourism expenditure and produces an aggregate tourism commodity. The tourism sector in our SAM does not generate value-added itself, but demands domestically produced services and goods (as detailed above), Additional exports of tourism therefore indirectly increases value-added in the Tanzanian economy.

An additional commodity account contains the aggregate tourism commodity (the output of the domestic tourism activity) and tourism imports. The sum of the two is exported as gross tourism exports.

The reallocation of tourism expenditure corresponds to a relocation of demands for output between sectors. To maintain a balanced SAM a final correction was needed to ensure that the value of output equals total demand in each sector. Capital earnings are increased in sectors where demand is increased, and decreased in sectors where demand is decreased.

\section{Share of market captured by multinational service providers.}


The market share captured by foreign banks is estimated based on asset data for all major banks operating in Tanzania as provided in Appendix II in Bank of Tanzania (2007). Foreign banks are identified as banks with a foreign ownership share of more than $20 \%$, and the market share is estimated as the share of assets held by foreign banks. Our central values are presented in the table on sensitivity analysis.

Share of Expatriate Labor Employed by Multinational Service Providers. The impact of liberalization of barriers to foreign direct investment in business services sectors on the demand for labor in these sectors will depend importantly on the share of expatriate labor used by multinational firms. We explain in the results section that despite the fact that multinationals use Tanzanian labor less intensively than their Tanzanian competitors, if multinationals use mostly Tanzanian labor, their expansion is likely to increase the demand for Tanzanian labor in these sectors. ${ }^{16}$ We obtained estimates of the share of expatriate labor or specialized technology not available to Tanzanian firms that is used by multinational service providers in Tanzania from the survey mentioned above. We found that multinational service providers use mostly local primary factor inputs and only small amounts of expatriate labor or specialized technology. Our estimated share of foreign inputs used by multinationals in Tanzania is presented in the table on sensitivity analysis.

\section{Results}

In our "full reform" scenario, we assume that regulatory barriers in business services sectors against both foreign direct investment and domestic investors are cut in half. (The ad valorem equivalent of the barriers against new domestic or multinational entrants is specified in table 4.) We also assume that tariffs, as specified in table 4 , are set at a uniform tariff level that leaves tariff revenue unchanged.

\footnotetext{
${ }^{16}$ See Markusen, Rutherford and Tarr (2005) for a detailed explanation on why FDI may be a partial equilibrium substitute for domestic labor but a general equilibrium complement.
} 
We first discuss (and present in table 5) our estimates of the full reform scenario. We assess the impact on aggregate variables such as welfare and the real exchange rate, aggregate exports, the return to capital, skilled labor, semi-skilled labor, unskilled labor and land, and the percentage change in tariff revenue. In order to obtain as assessment of the adjustment costs, we estimate the percentage of each of our five factors of production that would have to change industries. The gains come from a combination of effects, so we also estimate the comparative static impacts of the various components of the full reform scenario in order to assess their relative importance. We then discuss the results of our steady state scenario, where we allow the capital stock to adjust to its long run equilibrium. Finally, we show that the modeling formulation with endogenous productivity effects is crucial to the results by, for diagnostic purposes, considering a constant returns to scale model. After discussing the aggregate results, we discuss the impacts at the sector level, both in the comparative static and the comparative steady state models.

\section{Aggregate Effects}

We estimate that the welfare gains to Tanzania of full reform are equal to 5.3 percent of Tanzanian consumption (or 4.8 percent of GDP) in the medium term. In the long run, we estimate that the gains could be as high as 16 percent of consumption. These medium terms gains derive from three key effects: (1) removal of non-discriminatory inefficient regulatory barriers against service providers; (2) removal of regulatory barriers against multinational service providers in Tanzania; and (3) gains from moving to a uniform tariff. We execute several scenarios that allow us to understand the relative impact of these various elements and the mechanisms through which they operate. We discuss three of these below.

The improvement of aggregate welfare is accompanied by a significant increase in factor earnings including the wages of the various types of labor in our model (with the exception of females without a primary school education) ${ }^{17}$. Given the relatively strong expansion of business services (which intensively employs the two more educated relatively educated males), wages of the two more educated types of male labor increase relatively strongly. Our data indicates that the business services sectors are

\footnotetext{
${ }^{17}$ Females without formal education are employed more intensively in agriculture, which contracts relative to other sectors.
} 
the most capital intensive sectors in the economy, which explains why the return on capital increases by 5.7 percent. Land is used only in agriculture and agriculture experiences a slight contraction. Nonetheless, with Dixit-Stiglitz productivity gains, we escape the pessimism of Stolper-Samuelson and we observe an increase in agricultural rents, albeit at a more modest rate than other factors. ${ }^{18}$

The impact of the movement of workers is not strong as for most categories. Excpet for females without formal education, less than three percent must change jobs.

\section{Impact of Removing Non-discriminatory Regulatory Barriers against Tanzanian and}

Multinational Service Providers. In this scenario, labeled "only non-discriminatory services barriers," we reduce by 50 percent the ad valorem equivalent of the non-discriminatory barriers on domestic and multinational service providers in Tanzania, but there is no reduction in the discriminatory tax on multinationals in the services sectors; nor is there any movement toward tariff uniformity. At 3.7 percent of the value of Tanzanian consumption, the largest share of the gains derives from the liberalization of non-discriminatory regulatory barriers. The results are explained by the fact that the estimated barriers are rather high in the services sectors, especially in the water and rail transportation sectors. In addition, we assume that there are real resource costs of the barriers which are freed through the liberalization. The gains, however, are significantly less than Balerstreri, Rutherford and Tarr (2008) found in Kenya. This is explained by the fact that business services are a much more substantial part of the economy of Kenya than they are in Tanzania.

The reduction in the regulatory barriers on the provision of services in Tanzania reduces the cost of providing services in Tanzania for both Tanzanian and multinational service providers. This increases profitability for the provision of services in Tanzania, thereby inducing new entry by both domestic and multinational service providers until zero profits are restored. Consequently, there is an increase in new varieties of services. Tanzanian businesses will then have improved access to services in areas like telecommunication, banking, insurance, transportation and other business services. The additional service

\footnotetext{
${ }^{18}$ See Markusen, Rutherford and Tarr (2005) for an elaboration of impact of escaping Stolper-Samuelson effects in the presence of Dixit-Stiglitz effects.
} 
varieties in the business services sectors should lower the cost of doing business and result in a productivity improvement for users of these goods through the Dixit-Stiglitz-Ethier effect.

Impact of Foreign Direct Investment Liberalization in Business Services. In this scenario, labeled "only barriers against FDI in services," we reduce by 50 percent the ad valorem equivalent of the discriminatory barriers against multinational service providers who may wish to serve the Tanzanian market, but there is no reduction in the non-discriminatory tax equivalent of the regulatory burden on business service; nor is there any movement toward tariff uniformity. Reducing discriminatory barriers against multinational service providers yields a gain of 0.8 percent of Tanzanian consumption. The reduction in the discriminatory tax equivalent on multinational service providers increases profitability for multinational provision of services in Tanzania, thereby inducing new entry by multinational service providers until zero profits are restored. Although there is a loss of domestic service varieties due to increased competition from multinational service providers, there is a net increase in varieties. Tanzanian businesses will then have improved access to services.

Impact of Tariff Uniformity. In this scenario, labeled only tariffs, we impose tariff uniformity, but we do not change the ad valorem tax equivalent of regulatory barriers on domestic or multinational service providers. In moving to tariff uniformity, the average level of the Tanzanian tariff is unchanged. The level of the tariff is imposed that results in the same average collected tariff rate in Tanzania- the difference in the highs and lows are eliminated and replaced with a unique tariff for all sectors. Moving to uniform tariffs yields and estimated welfare gain of 0.2 percent of consumption. Our result of gains from tariff uniformity is consistent with the results of Martinez de Pereira (2000) in 13 countries and Harrison, Rutherford and Tarr (1993) for Turkey. These authors have found that moving to tariff uniformity results in welfare benefits. The reason is that the distortion costs of a tariff increase with the square on the tariff. Then moving to uniformity can be expected to benefit the country since it is the very high tariffs that cause the most of distortion costs. ${ }^{19}$ Moreover, the typical lobbying for protection environment in a country is one-sided as industry groups receive concentrated benefits and lobby but

\footnotetext{
${ }^{19}$ These results show that, in practice, tariffs do not differ from uniformity due to Ramsey optimal tax considerations.
} 
diverse consumer interests face a free-rider problem and typically do not lobby. Panagariya and Rodrik (1993) have shown, uniformity dramatically reduces the incentive to lobby the government for protection. And the experience of Chile shows that industry groups may lobby in favor of lower protection in such a case. Thus, in his evaluation of the arguments for and against tariff uniformity, Tarr (2002) has argued that the overwhelming advantage of a uniform tariff is that it is likely to lead to a lower level of protection due to the change in the political economy for protection.

Comparative Steady State Formulation. The increased availability of services results in an increase in the productivity of capital, which should increase the accumulation of capital and, in the longrun steady state, increase the capital stock. In this scenario, we allow the capital stock to adjust to its long run equilibrium

Then the gains to the Tanzanian economy increase to 15.9 percent of consumption or 14.4 percent of GDP per year. In this formulation, the incentive to accumulate more capital due to an increase in the marginal productivity of capital is taken into account, but the costs of foregone consumption to achieve the higher capitals stock are not taken into account. So in the context of this model, the estimates should be considered upper bound estimates. On the other hand, Rutherford and Tarr (2002) have shown that in a fully dynamic model with endogenous productivity effects, the gains can be even larger than those estimated here.

Constant Returns to Scale Formulation. In order to assess the importance of the modeling assumption of endogenous productivity effects from additional varieties, we also consider a "constant returns to scale" (CRTS) version of the model. In this version, there are no endogenous productivity effects from additional varieties of imperfectly supplied goods or services. We estimate that the gains fall to 1.9 percent of consumption or 1.7 percent of GDP. While this is considerably smaller than our estimates with endogenous productivity effects, the gains are large by the standards of CRTS trade models. The reason is that we are considering reforms of regulatory barriers against both foreign and domestic service providers and we assume that the regulatory barriers impose real resource costs in the initial equilibrium, i.e., there are large "rectangles of rent losses in the CRTS model. The value of 50 percent of the rents in the benchmark is 1.34 percent of GDP 


\section{Sector Results}

In tables 6,7 and 8 we present various sector results. In table 6 we present our estimates of the impact on employment by sector and the change in exports and imports by sector. In table 7, we present our estimates of the change in prices by sector and by scenario. In this discussion, we focus on the output effects by sector in the full reform (comparative static) and steady state scenarios. These results may be found in table 8 . We discuss the medium term results from our "full reform" scenario first and then our long run results from our steady state scenario.

Medium-Run Results. In the full reform scenario, reduction in the cost of business services (both from removal of regulatory barriers and from the Dixit-Stiglitz variety externality) leads to an increase in the demand for business services and their expansion. The expansion is greatest in the banking and insurance sectors, at 59 and 51 percent, respectively, including multinational output in these sectors; this is primarily explained by the fact that these sectors are among the sectors with the highest level of barriers (both non-discriminatory and discriminatory.

The tourism and hotel and restaurant sectors experience very strong output expansion. This is because these sectors, especially the tourism sector as explained above, are very intensive users of the business services sectors who quality adjusted real prices are significantly falling.

Given that we assume that total employment and the capital stock is fixed in the medium term, if labor expands in some sectors, it must contract in other sectors. Given the large expansion in several sectors, especially services, we must have declines in others in the medium term. We estimate declines in output in many sectors, especially those that use business services less intensively. Moreover, since we assume uniform tariffs in our full reform scenario, sugarcane, which is the one of the more highly protected sector, is estimated to decline. Finally, the reform depreciates the real exchange rate; so sectors that export intensively will benefit relative to those that do little exporting.

Long-Run Results. The basic pattern in the long run, i.e., the steady state scenario, is that we estimate very substantial expansion of the services sectors, and significant expansion in the nonagricultural sectors overall. The increasing returns to scale manufacturing sectors and the constant returns 
to scale manufacturing and services sectors expand on average at about 13-14 percent. Given that we have an expansion of the capital stock, we can have all sectors expanding; in fact, we also see a modest expansion of the agricultural sector. But, agriculture expands the least, so agricultural output declines as a share of GDP. These results are consistent with the empirically observed broad pattern of economic development: namely, as countries become wealthier, agricultural output becomes a smaller share of total output, without necessarily declining in absolute amounts.

In more detail, led by tourism and the hotels and restaurants sectors, with a very large expansion of 165 and 45 percent, respectively, the competitive sectors expand by 15 percent overall. We estimate that the imperfectly competitive part of the manufacturing sector will more expand by about 13 percent on average in the long run. All the imperfectly competitive manufacturing sectors expand in the long run except for "tobacco and leather products." The tobacco and leather products sector is the sector with the highest tariff protection in the economy, so the movement to uniform tariffs hits this sector relatively hard.

The reason for the general expansion of the manufacturing sector in the long run is two-fold. First, liberalization of the regulatory barriers in services reduces the costs of producing services. These gains would also be realized in a constant returns to scale model. We also allow for the fact that greater availability of varieties of business services allows sectors that use these services to purchase them at a reduced quality adjusted price, and this acts to increase the productivity of sectors that use business services. Finally, the increase in the productivity of capital, results in an improvement in the profitability of investment, and accumulation of capital and an increase in the capital stock in the steady state equilibrium. Then compared with the comparative static model, output can expand much more broadly in the economy in the new steady state equilibrium due to the greater capital stock.

\section{Sensitivity Results.}

We have discussed the impact of the constant returns to scale and steady state versus comparative static modeling assumptions above. We focus now on the impact of parameter assumptions on our 
comparative static results. We undertake piecemeal sensitivity analysis with respect to all the key parameters of the model and present these results in table 9.

Three parameters stand out as having a strong impact on the results. The strongest impact comes from $\sigma\left(q_{i}, q_{j}\right)$, the elasticity of substitution between firm varieties in imperfectly competitive sectors. Unlike other elasticities, a lower value of $\sigma\left(\mathrm{q}_{\mathrm{i}}, \mathrm{q}_{\mathrm{j}}\right)$ iincreases the welfare gains. This is because lower values of this elasticity imply that varieties are less close to each other, so additional varieties are worth more. The next strongest impact comes from $\sigma(\mathrm{va}, \mathrm{bs})$, the elasticity of substitution between value-added and business services. The better firms are able to substitute business services for labor and capital, the more the economy will gain from the reforms that reduce the quality adjusted price of business services. Finally, larger values of $\varepsilon\left(\mathrm{f}_{\mathrm{i}}\right)$, the elasticity of multinational service firm supply with respect to the price of output, also significantly increase the gains, since it means that reforms that open opportunities for multinational service firms, will not be so quickly choked by the increased cost of the specific factor required for multinational firm expansion.

\section{Lobbying Interests in the Business Services Sectors}

Tanzanian business and labor interests in these sectors are not the same, and we discuss the impact on labor in these sectors first. We find that skilled, semi-skilled and unskilled employment will expand in all the business services sectors, in some cases rather substantially. This is an application to a full economy model of the result found by Markusen, Rutherford and Tarr (2005). They have shown in a more stylized model that even when foreign direct investment is a partial equilibrium substitute for domestic skilled labor, it may be a general equilibrium complement. The reason is as follows. As a result of a reduction in the barriers to foreign direct investment in these sectors, we estimate that there will be an expansion in the number of multinational firms who locate in Tanzania to provide business services from within Tanzania, and a contraction in the number of purely Tanzanian firms. Although multinationals also demand Tanzanian labor, though they use Tanzanian labor slightly less intensively than Tanzanian firms, i.e., since multinationals import primary inputs, foreign direct investment is a partial equilibrium 
substitute for Tanzanian labor. But as more service firms enter the market, the quality adjusted price of services falls, and industries that use services expand their demand for business services. On balance, the increase in labor demand from the increase in the demand for business services typically exceeds the decline in labor demand from the substitution of multinational supply for Tanzanian supply in the Tanzanian market. That is, FDI is a partial equilibrium substitute but a general equilibrium complement to Tanzanian labor. Thus, we estimate that labor in the business services sectors will typically gain from an expansion in foreign direct investment and multinational provision of services in Tanzania.

Regarding capital, as a result of the removal of restrictions, we estimate there would be significant increase in foreign direct investment and an increase in multinational firms operating in Tanzania . We estimate that specific capital owners in imperfectly competitive sectors will lose from this increase in competition. We expect, however, that the increase in foreign direct investment to have diverse impacts on Tanzanian firms. We define a firm as a multinational even if a foreign firm and a Tanzanian firm have formed a joint venture. Multinationals will often look for Tanzanian joint venture partners when they want to invest in Tanzania. Tanzanian companies that become part of the joint ventures in the expanding multinational share of the business services market will likely preserve or increase the value of their investments. Tanzanian capital owners in business services who remain wholly independent of multinational firms, either because they avoid joint ventures or are not desired as joint venture partners, will likely see the value of their investments decline, and the least efficient will exit the industry. ${ }^{20}$

This suggests that domestic lobbying interests within a service sector could be diverse regarding FDI liberalization. We estimate that labor should find it in their interest to support FDI liberalization even if capital owners in the sector oppose it. But capital owners themselves may have diverse interests depending on their prospects for acquisition by multinationals.

\footnotetext{
${ }^{20}$ We assume that firms in the business services sectors must use a specific factor in order to produce output. This specific factor results in an upward sloping supply curve in each business services sector.
} 


\section{Conclusions}

In this paper we have developed an innovative small open economy computable general equilibrium model of the Tanzanian economy that is capable of assessing the impact of the liberalization of regulatory barriers against both domestic and multinational service providers. We find that the reform package we consider in this paper could provide very substantial gains to the Tanzanian economy. Reduction of the barriers against potential service providers, both foreign and domestic, is the largest source of the gains. Moving to tariff uniformity, could provide additional gains and provide an improved environment for the political economy of protection.

Reforms that lead to greater access to business services will improve the productivity of labor and capital in all the sectors of the economy. We find that in the long run, the increased productivity of capital will induce an accumulation of capital and an increase in the capital stock, which will result in a general expansion of Tanzanian manufacturing.

\section{References}

Bank of Tanzania (2007), Tanzania Tourism Sector Survey: The 2005 International Visitors' Exit Survey Report, October.

Bank of Tanzania, Directorate of Banking Supervision Annual Report 2006, 2007.

Bank of Tanzania, Balance of Payment Data for Services for the Years 2000-2006, unpublished data.

Broda, Christian and David Weinstein (2004), "Variety, Growth and World Welfare," American Economic Review, 94 (2), May, 139-144.

Brown, Drusilla, Alan Deardorf, Alan Fox and Robert Stern (1996), "Liberalization of Services Trade," in W. Martin and L. A. Winters, eds., The Uruguay Round and the Developing Countries, Cambridge: Cambridge University Press.

Brown, Drusilla and Robert Stern (2001), "Measurement and Modeling of the Economic Effects of Trade and Investment Barriers in Services," Review of International Economics, 9(2): 262-286.

Chinitz, B. (1961), “Contrast in agglomeration: New York and Pittsburgh,” American Economic Review, Papers and Proceedings, 51:279-89.

Daniels, P.W. (1985), Service Industries: A Geographical Appraisal, New York: Methuen \& Co. 
Dantzig, George and Alan Manne (1974), "A Complementary Algorithm for an Optimal Capital Path with Invariant Proportions," Journal of Economic Theory, 9, 312-323.

Dee, Philippa, Kevin Hanslow and Tien Phamduc (2003), "Measuring the Costs of Barriers to Trade in Services," in Takatoshi Ito and Anne Krueger (eds.), Trade in Services in the Asia-Pacific Region, Chicago: University of Chicago Press.

Dixit, A. and J. Stiglitz (1977), "Monopolistic Competition and Optimum Product Diversity," American Economic Review, 76(1):297-308.

Ethier, W.J. (1982), "National and International Returns to Scale in the Modern Theory of International Trade," American Economic Review, 72(2):389-405.

Francois, Joseph, Bradley McDonald and Hakan Nordstom (1996), "Assessing the Uruguay Round," in Will Martin and L. Alan Winters (eds.), The Uruguay Round and the Developing Countries, Cambridge: Cambridge University Press.

Fujita, Masahisa, Paul Krugman and Anthony J. Venables (1999), The Spatial Economy: Cities, Regions, and International Trade, Cambridge: MIT Press.

Hansen, Terje and Tjalling Koopmans (1972), "On the Definition and the Computation of a Capital Stock Invariant Under Optimization," Journal of Economic Theory, 5, 487-523

Harrison, Glenn, Thomas Rutherford and David Tarr (1997), "Quantifying the Uruguay Round," Economic Journal.

Harrison, Glenn, Thomas Rutherford and David Tarr (1993), "Trade Reform in the Partially Liberalized Economy of Turkey," The World Bank Economic Review, May.

Heston, Alan, Robert Summers and Bettina Aten (2006), Bettina, Penn World Table Version 6.2, Center for International Comparisons of Production, Income and Prices at the University of Pennsylvania, September.

Holmes, T. (1995), "Localization of Industry and Vertical Disintegration," Federal Reserve Bank of Minneapolis.

Hummels, D (1995), "Global Income Clustering and Trade in Intermediate Goods," Graduate School of Business, University of Chicago.

Jensen, Jesper, Thomas Rutherford and David Tarr (2007), "The Impact of Liberalizing Barriers to Foreign Direct Investment in Services: The Case of Russian Accession to the World Trade Organization," Review of Development Economics, Vol 11 (3), August, 2007, 482-506.

Kang, Joog-Soon (2000), "Price Impact of Restrictiveness on Maritime Transportation Services," in Findlay, Christopher and Tony Warren (eds), Impediments to Trade in Services: Measurement and Policy Implications, (London: Routledge).

Kimura, Fukunari, Mitsuyo Ando and Takamune Fujii (2004a), "Estimating the Ad Valorem Equivalent of Barriers to Foreign Direct Investment in the Telecommunications Services Sectors in Tanzania ." Available at http://www.worldbank.org/trade/russia-wto. 
Markusen, James R, Thomas Rutherford and David Tarr (2005), Trade and Direct Investment in Producer Services and the Domestic Market for Expertise," Canadian Journal of Economics, Vol 38 (3), 758-777.

Marshall, J.N. (1988), Services and Uneven Development, London: Oxford University Press.

Martinez de Prera, Josefina (2000), "Revenue-Neutral Tariff Reform: Welfare Effects of Uniform Tariffs in 13 Developing Countries," Chapter 3 of Ph.D Dissertation, University of Colorado. Available at http://ussub.colorado.edu/ martindp/

McGuire, Greg and Michael Schuele (2000), "Restrictiveness of International Trade in Banking Services," in Findlay, Christopher and Tony Warren (eds), Impediments to Trade in Services: Measurement and Policy Implications, (London: Routledge).

McKee, D.L. (1988), Growth, Development, and the Service Economy in the Third World, New York: Praeger Publishers.

Melitz, mark J. (2003), "The Impact of Trade on intra-industry reallocations and aggregate industry productivity," Econometrica, 71(6), 1695-1725.

Mircheva, Bladislava (2008), “Ad valorem equivalence to FDI restrictiveness, Tanzania” Washington D.C.: The World Bank, mimeo.

National Bureau of Statistics of Tanzania, Gross Domestic Product at Current Prices by Selected Economic Activities for the Years 2001-2006, unpublished data.

National Bureau of Statistics of Tanzania (2007), Revised National Accounts Estimates For Tanzania Mainland - Base Year, 2001, Dar es Salaam, July.

Panagariya, A and D. Rodrik (1993), "Political-Economy Arguments for a Uniform Tariff," International Economic Review.

Romer, Paul. (1994), "New Goods, Old Theory and the Welfare Costs of Trade Restrictions," Journal of Development Economics," 43(1), February, 5-38.

Rutherford, Thomas F. and David Tarr (forthcoming), "Poverty Effects of Russian WTO accession: modeling "real" households with endogenous productivity effects," Journal of International Economics.

Rutherford, Thomas F. and David Tarr (2003), "Regional Trading Arrangements for Chile: Do the Results Differ with a Dynamic Model?" Integration and Trade, Vol 7, Number 18, 117-139.

Rutherford, Thomas F. and David Tarr (2002), "Trade Liberalization and Endogenous Growth in a Small Open Economy," Journal of International Economics, 56 (2), March, 247-272

Rutherford, Thomas F. (1999), "Applied General Equilibrium Modeling with MPSGE as a GAMS Subsystem: An Overview of the Modeling Framework and Syntax", Computational Economics.

Tanzania Revenue Authority, Import Duties and Import Values for the Year 2006, unpublished data. 
Tarr, David (2008), "Policy Note on the Tanzanian Telecommunications Sector,"mimeo.

Tarr, David (2002), "On the Design of Tariff Policy: Arguments for and Against Uniform Tariffs," in B. Hoekman, A. Mattoo and P. English (eds.), Development, Trade and the WTO: A Handbook, Washington: World Bank.

Telecommunications Management Group, Inc.(2007), “Trade in Information and Communication Services: Opportunities for East and Southern Africa," Chapter on Tanzania, Draft report to the World Bank, January 31, pp.15-39.

Thurlow, James and Peter Wobst, Poverty-focused social accounting matrices for Tanzania, TMD Discussion paper no. 112, International Food Policy Research Institute, Washington D.C. USA, 2003.

United Nations Conference on Trade and Development and World Bank (1994), Liberalizing Trade in Services: A Handbook, New York and Geneva: United Nations.

United Nations Conference on Trade and Development, Division on Transnational Corporations and Investment (1995 and 1996), World Investment Report 1995 and 1996, New York and Geneva: United Nations.

Vernon, R. (1960), Metropolis 1985, Cambridge: Harvard University Press.

Warren, Tony (2000), "The Impact on Output of Impediments to Trade and Investment in Telecommunications Services," in Findlay, Christopher and Tony Warren (eds), Impediments to Trade in Services: Measurement and Policy Implications, (London: Routledge).

World Bank (2007), Tanzania: Unleashing the Potential for Trade and Growth, Report No. 37688-KE, World Bank: Washington, DC. Available at: http://imagebank.worldbank.org/servlet/WDSContentServer/IW3P/IB/2007/03/16/000310607_20070 316095914/Rendered/PDF/376880KE.pdf 
Table 1. List of sectors and factors of production

\begin{tabular}{|c|c|}
\hline Business Services & Agriculture \\
\hline Telecommunication & Maize \\
\hline Insurance & Paddy \\
\hline Banking & Sorghum or millets \\
\hline Professional business services & Wheat \\
\hline Air transport & Beans \\
\hline Road transport & Cassava \\
\hline Railway transport & Other cereals \\
\hline \multirow[t]{2}{*}{ Water transport } & Oil seeds \\
\hline & Other roots \& tubes \\
\hline IRTS Goods & Cotton \\
\hline Processed food & Coffee \\
\hline Beverages \& tobacco products & Tobacco \\
\hline Textile \& leather products & Tea \\
\hline Wood paper printing & Cashew nuts \\
\hline Manufacture of basic \& industrial chemicals & Sisal fiber \\
\hline Manufacture of fertilizers \& pesticides & Sugar \\
\hline Petroleum refineries & Fruits \& vegetables \\
\hline Rubber plastic \& other manufacturing & Other crops \\
\hline Glass \& cement & Poultry \& livestock \\
\hline \multicolumn{2}{|l|}{ Iron steel \& metal products } \\
\hline \multirow[t]{2}{*}{ Manufacture of equipment } & Other CRTS \\
\hline & Fish \\
\hline Factors of Production & Hunting \& forestry \\
\hline Child (age 10 to 14 ) & Mining \& quarrying \\
\hline Female (no formal education) & Meat \& dairy products \\
\hline Female (not finished primary school) & Grain milling \\
\hline Female (not finished secondary school) & Utilities \\
\hline Female (secondary or higher education) & Construction \\
\hline Male (no formal education) & Wholesale \& retail trade \\
\hline Male (not finished primary school) & Hotels \& restaurants \\
\hline Male (not finished secondary school) & Postal communication \\
\hline Male (secondary or higher education) & Real estate \\
\hline Subsistence & Other services \\
\hline Agricultural capital & Public administration health $\&$ education \\
\hline Capital & Tourism \\
\hline Land & \\
\hline
\end{tabular}


Table 2 Sectoral value-added (\%, unless otherwise indicated)

\begin{tabular}{|c|c|c|c|c|c|c|c|c|c|c|c|c|c|c|c|c|}
\hline & \multicolumn{9}{|c|}{ Labor } & \multirow[b]{2}{*}{ Subsistence } & \multirow[b]{2}{*}{ Capital } & \multirow[b]{2}{*}{ Land } & \multicolumn{2}{|c|}{ GDP } & \multicolumn{2}{|c|}{ Market shares } \\
\hline & $\begin{array}{c}\text { Child } \\
\text { (age 10 to } \\
14 \text { ) }\end{array}$ & $\begin{array}{c}\text { Female } \\
\text { (no formal } \\
\text { education) }\end{array}$ & $\begin{array}{l}\begin{array}{l}\text { Female } \\
\text { (not } \\
\text { finished } \\
\text { primary } \\
\text { school) }\end{array} \\
\end{array}$ & 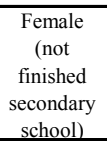 & $\begin{array}{c}\text { Female } \\
\text { (secondary } \\
\text { or higher } \\
\text { education) }\end{array}$ & $\begin{array}{c}\text { Male } \\
\text { (no formal } \\
\text { education) }\end{array}$ & $\begin{array}{l}\begin{array}{l}\text { Male } \\
\text { (not } \\
\text { finished } \\
\text { primary } \\
\text { school) }\end{array} \\
\end{array}$ & $\begin{array}{c}\begin{array}{c}\text { Male } \\
\text { (not } \\
\text { finished }\end{array} \\
\text { secondary } \\
\text { school) }\end{array}$ & $\begin{array}{c}\text { Male } \\
\text { (secondary } \\
\text { or higher } \\
\text { education) }\end{array}$ & & & & bnTZS & $\%$ of total & $\begin{array}{c}\begin{array}{c}\text { Domestic } \\
\text { firms }\end{array}\end{array}$ & $\begin{array}{c}\begin{array}{c}\text { Foreign } \\
\text { firms }\end{array} \\
\text { (a) }\end{array}$ \\
\hline IRTS Goods and Services & 0.1 & 0.3 & 0.4 & 6.1 & 4.0 & 0.5 & 2.6 & 19.2 & 10.5 & 4.5 & 52.0 & & 749.0 & 10.4 & & \\
\hline CRTS Goods and Services & 0.4 & 1.0 & 1.2 & 7.6 & 1.9 & 1.2 & 3.8 & 8.3 & 5.1 & 29.8 & 34.8 & 4.8 & 6426.2 & 89.6 & & \\
\hline Business Services & 0.1 & 0.1 & 0.3 & 3.6 & 4.1 & 0.4 & 2.1 & 15.3 & 15.1 & & 58.9 & & 278.5 & 3.9 & & \\
\hline Telecommunication & & & & 2.2 & 4.2 & 0.3 & 1.1 & 15.6 & 22.2 & & 54.3 & & 36.6 & 0.5 & 10.0 & 90.0 \\
\hline Insurance & 0.1 & 0.2 & 0.7 & 5.8 & 5.1 & 0.6 & 3.7 & 19.3 & 12.7 & & 51.7 & & 3.3 & 0.0 & 70.0 & 30.0 \\
\hline Banking & 0.1 & 0.2 & 0.7 & 5.8 & 5.1 & 0.6 & 3.7 & 19.3 & 12.7 & & 51.7 & & 58.2 & 0.8 & 60.0 & 40.0 \\
\hline Professional business services & 0.1 & 0.2 & 0.7 & 5.8 & 5.1 & 0.6 & 3.7 & 19.3 & 12.7 & & 51.7 & & 64.4 & 0.9 & 70.0 & 30.0 \\
\hline Air transport & & & & 1.4 & 2.6 & 0.2 & 0.7 & 9.9 & 14.0 & & 71.1 & & 12.2 & 0.2 & 60.0 & 40.0 \\
\hline Road transport & & & & 1.4 & 2.6 & 0.2 & 0.7 & 9.9 & 14.0 & & 71.1 & & 79.9 & 1.1 & 80.0 & 20.0 \\
\hline Railway transport & & & & 1.4 & 2.6 & 0.2 & 0.7 & 9.9 & 14.0 & & 71.1 & & 4.1 & 0.1 & 40.0 & 60.0 \\
\hline Water transport & & & & 2.2 & 4.2 & 0.3 & 1.1 & 15.6 & 22.2 & & 54.3 & & 19.9 & 0.3 & 20.0 & 80.0 \\
\hline Dixit-Stiglitz Goods & 0.1 & 0.5 & 0.4 & 7.5 & 3.9 & 0.6 & 2.8 & 21.4 & 7.7 & 7.1 & 47.9 & & 470.5 & 6.6 & & \\
\hline Processed food & & 0.4 & 0.1 & 1.0 & 6.1 & 0.5 & 0.8 & 7.4 & 4.7 & 25.2 & 53.7 & & 98.7 & 1.4 & & \\
\hline Beverages \& tobacco products & & & & 0.2 & 0.6 & & 0.0 & 1.6 & 23.7 & 20.4 & 53.5 & & 42.6 & 0.6 & & \\
\hline Textile \& leather products & 0.2 & 1.1 & 1.0 & 18.8 & 6.2 & 0.5 & 5.3 & 28.2 & 6.7 & & 32.0 & & 176.0 & 2.5 & & \\
\hline Wood paper printing & 0.0 & 0.1 & & 0.4 & 0.9 & 2.2 & 1.7 & 25.6 & 6.2 & & 62.9 & & 44.8 & 0.6 & & \\
\hline Manufacture of basic \& industrial chemicals & & & & & & & & 87.7 & & & 12.3 & & 15.1 & 0.2 & & \\
\hline Manufacture of fertilizers \& pesticides & & & & & & & & 82.6 & & & 17.4 & & 2.5 & 0.0 & & \\
\hline Petroleum refineries & & & & & & & & 38.5 & 4.5 & & 57.0 & & 8.6 & 0.1 & & \\
\hline Rubber plastic \& other manufacturing & & & & 6.7 & 3.5 & & 0.5 & 18.1 & 6.2 & & 64.9 & & 10.7 & 0.1 & & \\
\hline Glass \& cement & & 0.2 & 0.0 & 0.1 & & 0.3 & 0.6 & 29.1 & 5.4 & & 64.4 & & 19.2 & 0.3 & & \\
\hline Iron steel \& metal products & & & & & 0.7 & 1.9 & 4.9 & 17.0 & 12.8 & & 62.7 & & 25.7 & 0.4 & & \\
\hline Manufacture of equipment & & & & 0.9 & 0.4 & & 3.9 & 4.9 & 6.0 & & 84.0 & & 26.5 & 0.4 & & \\
\hline
\end{tabular}


Table 2. (continued)

\begin{tabular}{|c|c|c|c|c|c|c|c|c|c|c|c|c|c|c|c|c|}
\hline & \multicolumn{9}{|c|}{ Labor } & \multirow[b]{2}{*}{ Subsistence } & \multirow[b]{2}{*}{ Capital } & \multirow[b]{2}{*}{ Land } & \multicolumn{2}{|c|}{ GDP } & \multicolumn{2}{|c|}{ Market shares } \\
\hline & $\begin{array}{l}\text { Child } \\
\text { (age 10 to } \\
\text { 14) }\end{array}$ & $\begin{array}{c}\text { Female } \\
\text { (no formal } \\
\text { education) }\end{array}$ & $\begin{array}{l}\text { Female } \\
\text { (not } \\
\text { finished } \\
\text { primary } \\
\text { school) } \\
\end{array}$ & $\begin{array}{c}\begin{array}{c}\text { Female } \\
\text { (not } \\
\text { finished } \\
\text { secondary } \\
\text { school) }\end{array} \\
\end{array}$ & $\begin{array}{c}\text { Female } \\
\text { (secondary } \\
\text { or higher } \\
\text { education) }\end{array}$ & $\begin{array}{c}\text { Male } \\
\text { (no formal } \\
\text { education) }\end{array}$ & 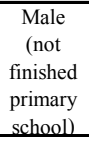 & $\begin{array}{c}\begin{array}{c}\text { Male } \\
\text { (not } \\
\text { finished } \\
\text { secondary } \\
\text { school) }\end{array} \\
\end{array}$ & $\begin{array}{c}\text { Male } \\
\text { (secondary } \\
\text { or higher } \\
\text { education) }\end{array}$ & & & & bnTZS & $\%$ of total & 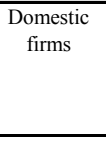 & $\begin{array}{c}\begin{array}{c}\text { Foreign } \\
\text { firms }\end{array} \\
\text { (n) }\end{array}$ \\
\hline Agriculture & 0.7 & 1.9 & 2.3 & 12.0 & 0.1 & 1.5 & 5.3 & 5.1 & 0.3 & 40.1 & 22.1 & 8.4 & 2998.2 & 41.8 & & \\
\hline Maize & 0.2 & 1.8 & 1.2 & 7.9 & 0.0 & 0.8 & 2.2 & 2.5 & 0.2 & 68.2 & 10.5 & 4.5 & 750.2 & 10.5 & & \\
\hline Paddy & 0.2 & 1.9 & 2.1 & 18.7 & 0.1 & 1.1 & 6.3 & 8.4 & 0.7 & 23.1 & 26.3 & 11.2 & 283.5 & 4.0 & & \\
\hline Sorghum or millets & 0.4 & 3.9 & 0.6 & 5.1 & & 1.8 & 2.0 & 2.9 & 0.1 & 66.4 & 11.7 & 5.0 & 100.1 & 1.4 & & \\
\hline Wheat & & & & & & & & 47.3 & & 5.4 & 33.1 & 14.1 & 17.5 & 0.2 & & \\
\hline Beans & & 3.8 & 2.5 & 20.3 & 0.1 & 1.0 & 4.0 & 3.3 & 0.2 & 30.4 & 24.1 & 10.3 & 178.4 & 2.5 & & \\
\hline Cassava & 0.1 & 1.1 & 0.6 & 3.4 & 0.0 & 0.6 & 2.0 & 1.6 & 0.2 & 81.2 & 6.5 & 2.8 & 152.0 & 2.1 & & \\
\hline Other cereals & 0.5 & 5.5 & 2.3 & 19.3 & 0.1 & 2.7 & 6.3 & 6.9 & 0.4 & 12.2 & 30.7 & 13.1 & 25.7 & 0.4 & & \\
\hline Oil seeds & 0.6 & 3.3 & 1.6 & 16.9 & & 2.3 & 6.6 & 5.0 & 0.2 & 26.9 & 25.9 & 10.8 & 114.1 & 1.6 & & \\
\hline Other roots \& tubes & 0.8 & 1.6 & 1.3 & 11.9 & & & 4.2 & 3.6 & 0.2 & 53.2 & 16.2 & 6.9 & 122.7 & 1.7 & & \\
\hline Cotton & 4.4 & 0.9 & 2.7 & 10.4 & & 2.5 & 9.7 & 11.9 & 0.1 & & 44.6 & 12.7 & 56.1 & 0.8 & & \\
\hline Coffee & & 1.6 & 0.9 & 11.5 & & 1.7 & 6.7 & 11.5 & 0.5 & 6.3 & 49.0 & 10.2 & 76.9 & 1.1 & & \\
\hline Tobacco & & 2.3 & 1.8 & 12.0 & 0.2 & 2.7 & 8.4 & 11.3 & 1.8 & & 47.5 & 12.0 & 50.5 & 0.7 & & \\
\hline Tea & & & & & & & 39.2 & & & 1.2 & 47.8 & 11.7 & 26.2 & 0.4 & & \\
\hline Cashew nuts & 0.8 & 2.5 & 0.5 & 8.3 & & 4.4 & 9.8 & 13.7 & & & 48.2 & 11.9 & 98.2 & 1.4 & & \\
\hline Sisal fiber & & 5.4 & & & & 13.7 & 11.1 & 16.7 & 3.1 & & 35.0 & 15.0 & 7.1 & 0.1 & & \\
\hline Sugar & & & 26.8 & & & & 22.3 & & & 1.5 & 35.3 & 14.2 & 123.1 & 1.7 & & \\
\hline Fruits \& vegetables & 0.7 & 1.2 & 1.0 & 16.2 & 0.3 & 1.7 & 3.7 & 5.2 & 0.4 & 40.1 & 21.0 & 8.5 & 504.5 & 7.0 & & \\
\hline Other crops & 1.1 & 1.0 & & 11.8 & 0.1 & 3.5 & 6.9 & 2.8 & 0.2 & 43.7 & 20.7 & 8.2 & 61.4 & 0.9 & & \\
\hline Poultry \& livestock & 3.9 & 2.4 & 1.0 & 17.6 & 0.8 & 3.5 & 5.4 & 5.8 & 0.7 & 18.4 & 28.4 & 11.9 & 250.1 & 3.5 & & \\
\hline Other CRTS & 0.0 & 0.3 & 0.3 & 3.7 & 3.5 & 1.0 & 2.5 & 11.2 & 9.3 & 20.8 & 45.8 & 1.7 & 3427.9 & 47.8 & & \\
\hline Fish & & 1.9 & & 3.2 & & 6.5 & 14.9 & 18.6 & & 6.0 & 35.6 & 13.3 & 316.5 & 4.4 & & \\
\hline Hunting \& forestry & & & & 11.1 & & 1.1 & & 7.5 & 0.8 & 59.4 & 14.1 & 5.9 & 279.8 & 3.9 & & \\
\hline Mining \& quarrying & 0.1 & 0.1 & 0.0 & 0.0 & 0.1 & & 0.1 & 1.3 & 0.1 & & 98.3 & & 114.8 & 1.6 & & \\
\hline Meat \& dairy products & & & & 0.1 & 0.2 & 0.0 & 0.2 & 0.5 & 0.0 & 87.2 & 11.8 & & 176.3 & 2.5 & & \\
\hline Grain milling & 0.3 & 0.5 & 3.5 & 24.8 & & 1.6 & 2.2 & 34.3 & 7.3 & & 25.5 & & 51.9 & 0.7 & & \\
\hline Utilities & & & & 0.5 & 0.4 & 1.1 & 0.8 & 8.0 & 9.4 & & 79.9 & & 131.7 & 1.8 & & \\
\hline Construction & 0.2 & 0.1 & & 0.3 & 0.7 & 1.4 & 7.4 & 46.7 & 11.1 & & 32.2 & & 340.8 & 4.8 & & \\
\hline Wholesale \& retail trade & 0.0 & 0.1 & 0.2 & 1.3 & 0.4 & 0.2 & 0.5 & 3.0 & 2.2 & & 92.2 & & 792.2 & 11.0 & & \\
\hline Hotels \& restaurants & 0.0 & 0.9 & 1.3 & 6.6 & 0.6 & 0.0 & 0.2 & 5.1 & 2.3 & & 82.9 & & 271.4 & 3.8 & & \\
\hline Postal communication & & & & 1.5 & 2.7 & 0.2 & 0.7 & 10.1 & 14.4 & & 70.4 & & 4.0 & 0.1 & & \\
\hline Real estate & & & & 0.0 & 0.6 & & 0.0 & 0.7 & 4.2 & 82.4 & 12.0 & & 452.1 & 6.3 & & \\
\hline Other services & 0.1 & 0.1 & 0.5 & 3.9 & 3.4 & 0.4 & 2.4 & 12.7 & 8.4 & & 68.2 & & 36.1 & 0.5 & & \\
\hline Public administration health \& education & & 0.1 & 0.4 & 8.9 & 23.3 & 0.2 & 1.4 & 14.8 & 46.8 & & 4.2 & & 460.3 & 6.4 & & \\
\hline
\end{tabular}


Table 3. Trade flows

\begin{tabular}{|c|c|c|c|c|c|c|}
\hline & \multicolumn{3}{|c|}{ Imports } & \multicolumn{3}{|c|}{ Exports } \\
\hline & bnTZS & $\%$ of total & $\%$ of supply & bnTZS & $\%$ of total & $\%$ of output \\
\hline IRTS Goods and Services & 1198.7 & 71.6 & 32.0 & 207.5 & 16.4 & 9.9 \\
\hline CRTS Goods and Services & 475.7 & 28.4 & 5.2 & 1055.9 & 83.6 & 10.8 \\
\hline Business Services & 183.0 & 10.9 & 21.4 & 158.1 & 12.5 & 23.7 \\
\hline Telecommunication & 32.3 & 1.9 & 21.2 & 12.1 & 1.0 & 10.8 \\
\hline Insurance & 2.1 & 0.1 & 26.7 & 3.1 & 0.2 & 43.8 \\
\hline Banking & 36.8 & 2.2 & 26.7 & 55.3 & 4.4 & 43.8 \\
\hline Professional business services & 40.7 & 2.4 & 26.7 & 61.2 & 4.8 & 43.8 \\
\hline Air transport & 6.8 & 0.4 & 16.6 & 2.5 & 0.2 & 9.0 \\
\hline Road transport & 44.6 & 2.7 & 16.6 & 16.6 & 1.3 & 9.0 \\
\hline Railway transport & 2.3 & 0.1 & 16.6 & 0.8 & 0.1 & 9.0 \\
\hline Water transport & 17.5 & 1.0 & 21.2 & 6.5 & 0.5 & 10.8 \\
\hline Dixit-Stiglitz Goods & 1015.7 & 60.7 & 34.9 & 49.3 & 3.9 & 3.5 \\
\hline Processed food & 56.8 & 3.4 & 12.6 & 6.8 & 0.5 & 1.9 \\
\hline Beverages \& tobacco products & 11.6 & 0.7 & 7.3 & 1.1 & 0.1 & 0.8 \\
\hline Textile \& leather products & 54.7 & 3.3 & 14.0 & 16.3 & 1.3 & 4.5 \\
\hline Wood paper printing & 50.5 & 3.0 & 25.4 & 5.4 & 0.4 & 4.5 \\
\hline Manufacture of basic \& industrial chemicals & 85.9 & 5.1 & 48.0 & 3.1 & 0.2 & 4.8 \\
\hline Manufacture of fertilizers \& pesticides & 9.3 & 0.6 & 38.4 & 0.1 & 0.0 & 0.5 \\
\hline Petroleum refineries & 180.2 & 10.8 & 65.3 & 0.1 & 0.0 & 0.5 \\
\hline Rubber plastic \& other manufacturing & 48.2 & 2.9 & 41.4 & 1.3 & 0.1 & 2.6 \\
\hline Glass \& cement & 5.2 & 0.3 & 5.9 & 6.5 & 0.5 & 8.3 \\
\hline Iron steel \& metal products & 96.4 & 5.8 & 37.3 & 1.0 & 0.1 & 0.9 \\
\hline Manufacture of equipment & 416.9 & 24.9 & 62.7 & 7.6 & 0.6 & 8.0 \\
\hline Agriculture & 117.6 & 7.0 & 5.5 & 328.7 & 26.0 & 13.2 \\
\hline Maize & 16.7 & 1.0 & 3.7 & 1.0 & 0.1 & 0.2 \\
\hline Paddy & 20.5 & 1.2 & 6.5 & 2.4 & 0.2 & 0.7 \\
\hline Sorghum or millets & 0.0 & 0.0 & 0.0 & 0.1 & 0.0 & 0.1 \\
\hline Wheat & 18.9 & 1.1 & 42.4 & 0.0 & 0.0 & 0.2 \\
\hline Beans & 0.0 & 0.0 & 0.0 & 1.0 & 0.1 & 0.6 \\
\hline Cassava & 0.0 & 0.0 & 0.0 & 0.0 & 0.0 & 0.0 \\
\hline Other cereals & 0.0 & 0.0 & 0.0 & 0.1 & 0.0 & 0.4 \\
\hline Oil seeds & 0.3 & 0.0 & 0.3 & 4.0 & 0.3 & 4.2 \\
\hline Other roots \& tubes & 0.0 & 0.0 & 0.0 & & & \\
\hline Cotton & 0.0 & 0.0 & 0.0 & 36.7 & 2.9 & 35.1 \\
\hline Coffee & 0.0 & 0.0 & 0.0 & 83.8 & 6.6 & 81.3 \\
\hline Tobacco & 0.1 & 0.0 & 0.4 & 42.5 & 3.4 & 50.4 \\
\hline Tea & 0.2 & 0.0 & 1.0 & 23.3 & 1.8 & 53.0 \\
\hline Cashew nuts & 0.0 & 0.0 & 0.0 & 87.2 & 6.9 & 81.3 \\
\hline \multicolumn{7}{|l|}{ Sisal fiber } \\
\hline Sugar & 49.9 & 3.0 & 27.5 & 12.0 & 0.9 & 7.4 \\
\hline Fruits \& vegetables & 7.6 & 0.5 & 2.2 & 24.3 & 1.9 & 6.9 \\
\hline Other crops & 0.1 & 0.0 & 0.3 & 4.2 & 0.3 & 10.4 \\
\hline Poultry \& livestock & 3.2 & 0.2 & 1.3 & 6.1 & 0.5 & 2.5 \\
\hline Other CRTS & 71.3 & 4.3 & 1.1 & 188.1 & 14.9 & 2.8 \\
\hline Fish & 0.1 & 0.0 & 0.1 & 62.1 & 4.9 & 18.4 \\
\hline Hunting \& forestry & 0.6 & 0.0 & 0.3 & 5.2 & 0.4 & 3.1 \\
\hline Mining \& quarrying & 14.7 & 0.9 & 11.3 & 18.9 & 1.5 & 14.3 \\
\hline Meat $\&$ dairy products & 3.5 & 0.2 & 1.7 & 0.6 & 0.0 & 0.2 \\
\hline Grain milling & 15.2 & 0.9 & 2.4 & 6.5 & 0.5 & 1.0 \\
\hline \multicolumn{7}{|l|}{ Utilities } \\
\hline Construction & 2.4 & 0.1 & 0.3 & & & \\
\hline \multicolumn{7}{|l|}{ Wholesale \& retail trade } \\
\hline \multicolumn{7}{|l|}{ Hotels \& restaurants } \\
\hline Postal communication & 2.3 & 0.1 & 21.2 & 0.9 & 0.1 & 9.1 \\
\hline \multicolumn{7}{|l|}{ Real estate } \\
\hline Other services & 15.0 & 0.9 & 26.7 & 22.6 & 1.8 & 35.4 \\
\hline Tourism & 286.8 & 17.1 & 100.0 & 539.1 & 42.7 & 100.0 \\
\hline Public administration health \& education & 17.4 & 1.0 & 1.1 & 71.3 & 5.6 & 4.5 \\
\hline
\end{tabular}




\section{Table 4. Benchmark distortions}

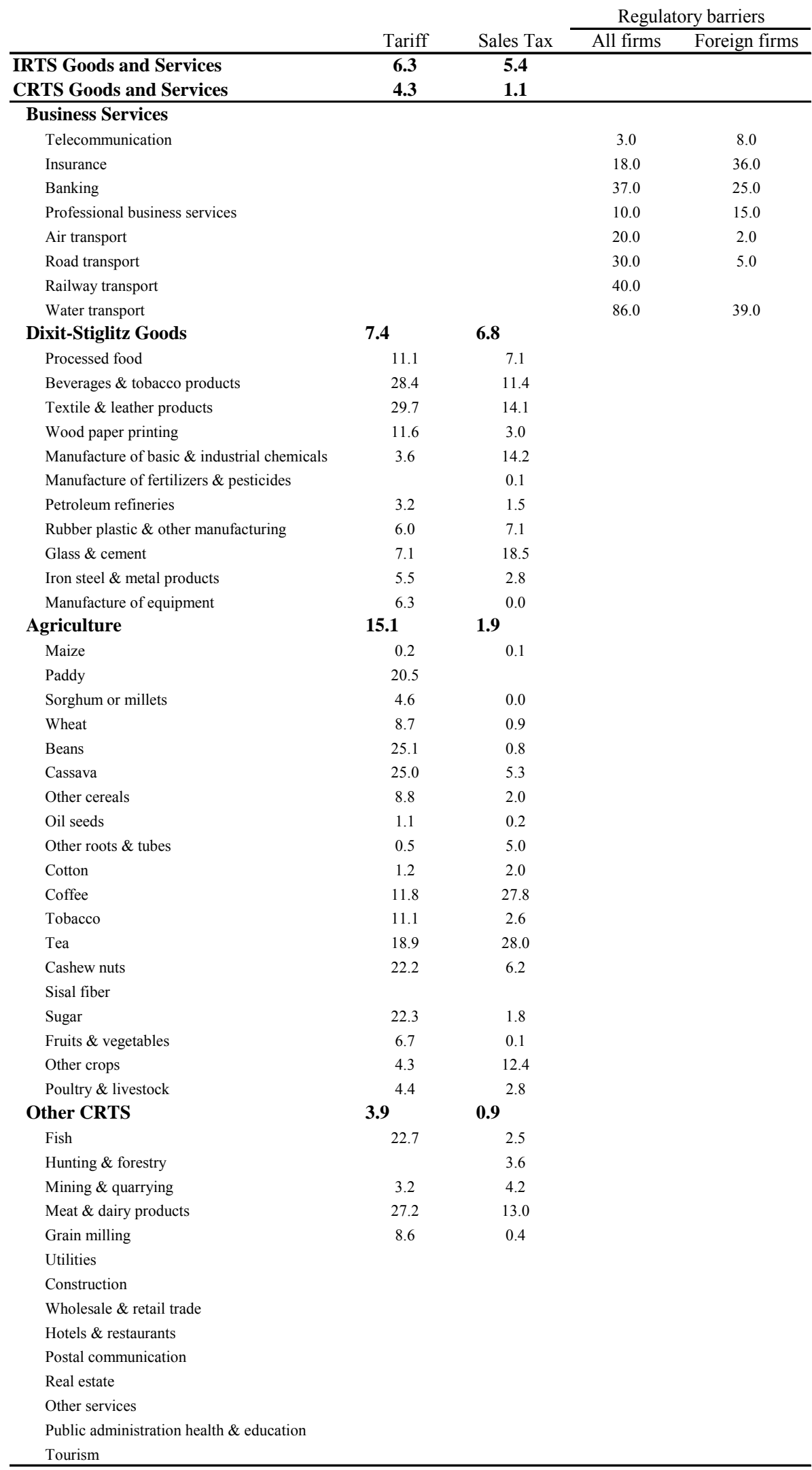


Table 5. Summary of Results (\%-change from initial equilibrium, unless otherwise indicated)

\begin{tabular}{|c|c|c|c|c|c|c|c|c|}
\hline Scenario definition & Benchmark & Full Reform & $\begin{array}{c}\text { All services } \\
\text { barriers }\end{array}$ & $\begin{array}{c}\text { Only non- } \\
\text { discrimina- } \\
\text { tory services } \\
\text { barriers }\end{array}$ & $\begin{array}{c}\text { Only } \\
\text { barriers } \\
\text { against FDI } \\
\text { in services }\end{array}$ & $\begin{array}{c}\text { Only } \\
\text { uniform } \\
\text { tariffs }\end{array}$ & CRTS & Steady State \\
\hline Liberalization of regulatory barriers for all services firms & No & Yes & Yes & Yes & No & No & Yes & Yes \\
\hline Liberalization of discriminatory barriers on foreign services firms & No & Yes & Yes & No & Yes & No & Yes & Yes \\
\hline Uniform import tariffs? & No & Yes & No & No & No & Yes & Yes & Yes \\
\hline Steady-state capital stock & No & No & No & No & No & No & No & Yes \\
\hline Dixit-Stiglitz variety-induced productivity gains & Yes & Yes & Yes & Yes & Yes & Yes & No & Yes \\
\hline \multicolumn{9}{|l|}{ Aggregate welfare } \\
\hline Welfare (EV as \% of consumption) & & 5.3 & 5.0 & 3.7 & 0.8 & 0.2 & 1.9 & 15.9 \\
\hline Welfare (EV as \% of GDP) & & 4.8 & 4.5 & 3.3 & 0.7 & 0.2 & 1.7 & 14.4 \\
\hline \multicolumn{9}{|l|}{ Government budget } \\
\hline Tariff revenue ( $\%$ of GDP) & 1.3 & 1.2 & 1.3 & 1.3 & 1.3 & 1.3 & 1.2 & 1.0 \\
\hline Tariff revenue & & 0.0 & 11.3 & 9.6 & 1.0 & 0.0 & 0.0 & \\
\hline \multicolumn{9}{|l|}{ Aggregate trade } \\
\hline Real exchange rate & & -1.6 & -2.4 & -2.3 & 0.1 & 0.6 & -0.7 & -4.9 \\
\hline Aggregate exports & & 31.4 & 17.3 & 16.3 & -0.3 & 9.5 & 13.0 & 71.4 \\
\hline \multicolumn{9}{|l|}{ Factor Earnings } \\
\hline Subsistence Factor & & 6.5 & 5.8 & 4.4 & 0.9 & 0.4 & 2.3 & 21.7 \\
\hline Child labor (age 10 to 14 ) & & 4.7 & 4.1 & 3.1 & 0.5 & 0.3 & 1.6 & 19.2 \\
\hline Female labor (no formal education) & & 5.6 & 4.3 & 3.3 & 0.4 & 1.0 & 1.9 & 20.0 \\
\hline Female labor (not finished primary school) & & -2.2 & 2.5 & 1.6 & 0.7 & -4.4 & -3.7 & 6.3 \\
\hline Female labor (not finished secondary school) & & 5.0 & 4.6 & 3.4 & 0.7 & 0.1 & 1.7 & 18.3 \\
\hline Female labor (secondary or higher education) & & 3.2 & 3.1 & 1.9 & 1.1 & -0.1 & 1.4 & 12.7 \\
\hline Male labor (no formal education) & & 4.8 & 3.1 & 2.3 & 0.2 & 1.4 & 1.6 & 19.7 \\
\hline Male labor (not finished primary school) & & 2.4 & 2.6 & 1.7 & 0.4 & -0.4 & -0.1 & 16.8 \\
\hline Male labor (not finished secondary school) & & 4.4 & 4.0 & 2.7 & 0.9 & 0.3 & 1.7 & 20.6 \\
\hline Male labor (secondary or higher education) & & 4.3 & 3.9 & 2.6 & 1.2 & 0.2 & 1.9 & 16.2 \\
\hline Capital & & 5.7 & 4.3 & 3.2 & 0.7 & 1.0 & 2.2 & -6.9 \\
\hline Agricultural land & & 3.6 & 2.9 & 2.2 & 0.2 & 0.4 & 0.5 & 17.2 \\
\hline \multicolumn{9}{|l|}{ Factor adjustments } \\
\hline Subsistence Factor & & 0.5 & 0.4 & 0.3 & 0.1 & 0.2 & 0.3 & 1.0 \\
\hline Child labor (age 10 to 14 ) & & 1.4 & 1.1 & 0.8 & 0.3 & 0.9 & 0.5 & 1.2 \\
\hline Female labor (no formal education) & & 1.3 & 1.4 & 1.1 & 0.4 & 0.9 & 0.7 & 1.7 \\
\hline Female labor (not finished primary school) & & 5.2 & 2.1 & 1.8 & 0.3 & 3.0 & 3.6 & 7.5 \\
\hline Female labor (not finished secondary school) & & 1.9 & 1.4 & 1.1 & 0.3 & 0.9 & 0.9 & 2.5 \\
\hline Female labor (secondary or higher education) & & 2.4 & 2.1 & 1.5 & 0.5 & 0.7 & 1.1 & 3.6 \\
\hline Male labor (no formal education) & & 1.3 & 1.6 & 1.2 & 0.6 & 1.0 & 0.6 & 1.7 \\
\hline Male labor (not finished primary school) & & 2.8 & 2.0 & 1.5 & 0.5 & 1.7 & 1.7 & 4.0 \\
\hline Male labor (not finished secondary school) & & 2.4 & 2.0 & 1.5 & 0.5 & 1.0 & 1.0 & 4.0 \\
\hline Male labor (secondary or higher education) & & 2.7 & 2.4 & 1.8 & 0.6 & 0.5 & 1.2 & 4.8 \\
\hline Capital & & 2.7 & 2.4 & 1.9 & 0.5 & 1.0 & 1.3 & 0.1 \\
\hline Agricultural land & & 2.0 & 1.7 & 1.4 & 0.5 & 1.2 & 1.3 & 2.4 \\
\hline Capital stock and investment & & & & & & & & 27.1 \\
\hline
\end{tabular}

Source: Authors' estimates. 
Table 6. Impact on industry of full reform (\%-change from initial equilibrium)

\begin{tabular}{|c|c|c|c|c|c|}
\hline & \multirow{2}{*}{\multicolumn{3}{|c|}{ Activity }} & \multirow{2}{*}{\multicolumn{2}{|c|}{ Factors }} \\
\hline & & & & & \\
\hline & Output & Exports & Imports & Capital & Land \\
\hline IRTS Goods and Services & 11.4 & 33.7 & 5.0 & 5.6 & \\
\hline CRTS Goods and Services & 7.0 & 31.0 & 63.0 & -1.0 & 0.0 \\
\hline Business Services & 37.5 & 48.2 & -34.2 & 21.4 & \\
\hline Telecommunication & 21.7 & 32.1 & -10.5 & 2.6 & \\
\hline Insurance & 51.2 & 54.4 & -37.5 & 34.4 & \\
\hline Banking & 59.2 & 62.5 & -52.4 & 41.6 & \\
\hline Professional business services & 39.9 & 42.9 & -16.8 & 24.4 & \\
\hline Air transport & 31.6 & 35.1 & -22.1 & 16.1 & \\
\hline Road transport & 35.1 & 38.7 & -37.7 & 19.2 & \\
\hline Railway transport & 35.0 & 38.6 & -39.1 & 19.1 & \\
\hline Water transport & 24.5 & 35.2 & -74.7 & 5.0 & \\
\hline Dixit-Stiglitz Goods & -0.9 & -11.5 & 12.1 & -6.0 & \\
\hline Processed food & 4.8 & 1.8 & 23.5 & 0.8 & \\
\hline Beverages \& tobacco products & 0.1 & -10.0 & 88.6 & -6.9 & \\
\hline Textile \& leather products & -8.9 & -20.6 & 97.4 & -12.2 & \\
\hline Wood paper printing & -4.2 & -15.3 & 24.9 & -8.2 & \\
\hline Manufacture of basic \& industrial chemicals & 5.8 & -1.3 & 3.5 & -3.6 & \\
\hline Manufacture of fertilizers \& pesticides & 0.5 & -18.9 & -4.4 & -1.5 & \\
\hline Petroleum refineries & 6.5 & -6.3 & 5.0 & -1.2 & \\
\hline Rubber plastic \& other manufacturing & 2.9 & -4.2 & 6.4 & -5.4 & \\
\hline Glass \& cement & 0.9 & -9.4 & 13.1 & -5.5 & \\
\hline Iron steel \& metal products & 1.3 & -6.3 & 3.1 & -4.0 & \\
\hline Manufacture of equipment & -2.0 & -9.5 & 3.5 & -5.9 & \\
\hline Agriculture & -1.0 & -20.4 & 41.4 & -2.9 & -0.4 \\
\hline Maize & 1.6 & -22.5 & 2.6 & 1.2 & 3.3 \\
\hline Paddy & -2.4 & -19.3 & 80.0 & -4.4 & -2.4 \\
\hline Sorghum or millets & 2.8 & -15.3 & 12.6 & 0.6 & 2.7 \\
\hline Wheat & -5.7 & -19.9 & 15.1 & -8.1 & -6.3 \\
\hline Beans & 2.2 & -21.0 & 134.0 & 1.3 & 3.4 \\
\hline Cassava & 0.3 & -26.7 & 135.9 & 0.7 & 2.8 \\
\hline Other cereals & 2.3 & -18.7 & 34.6 & 1.2 & 3.2 \\
\hline Oil seeds & 2.0 & -21.5 & 6.1 & 1.1 & 3.2 \\
\hline Other roots \& tubes & 1.6 & & 5.5 & 1.5 & 3.6 \\
\hline Cotton & -4.1 & -14.3 & -4.9 & -9.1 & -7.2 \\
\hline Coffee & -13.1 & -31.5 & 309.0 & -14.8 & -13.0 \\
\hline Tobacco & 12.5 & 5.5 & 51.0 & 4.0 & 6.1 \\
\hline Tea & -2.4 & -17.1 & 119.4 & -6.3 & -4.3 \\
\hline Cashew nuts & -4.5 & -25.3 & 576.9 & -5.7 & -3.8 \\
\hline Sisal fiber & -8.9 & & & -12.2 & -10.5 \\
\hline Sugar & -14.9 & -21.0 & 51.6 & -18.9 & -17.3 \\
\hline Fruits \& vegetables & 0.8 & -23.5 & 30.6 & 0.3 & 2.4 \\
\hline Other crops & 3.0 & -20.3 & 25.4 & 2.4 & 4.5 \\
\hline Poultry \& livestock & 1.6 & -19.8 & 16.2 & 0.2 & 2.2 \\
\hline Other CRTS & 4.0 & -13.0 & 24.1 & -0.1 & 1.9 \\
\hline Fish & 0.8 & -20.4 & 131.3 & -0.2 & 1.8 \\
\hline Hunting \& forestry & 1.1 & -21.2 & -0.6 & -0.1 & 2.0 \\
\hline Mining \& quarrying & 0.8 & -20.3 & 16.4 & -0.5 & \\
\hline Meat \& dairy products & -0.1 & -22.8 & 152.1 & 0.3 & \\
\hline Grain milling & 3.1 & -13.7 & 29.3 & 0.3 & \\
\hline Utilities & 3.1 & & & -2.0 & \\
\hline Construction & 1.9 & & 15.0 & -2.3 & \\
\hline Wholesale \& retail trade & 2.6 & & & -3.7 & \\
\hline Hotels \& restaurants & 18.2 & & & 13.7 & \\
\hline Postal communication & 8.6 & 11.8 & 4.8 & -4.4 & \\
\hline Real estate & 6.7 & & & 2.2 & \\
\hline Other services & 6.5 & 2.6 & 15.0 & -2.2 & \\
\hline Tourism & 81.5 & 81.5 & 81.5 & & \\
\hline Public administration health $\&$ education & 0.9 & -8.6 & 12.3 & -4.7 & \\
\hline
\end{tabular}

Source: Authors' estimates. 
Table 6 (continued)

\begin{tabular}{|c|c|c|c|c|c|c|c|c|c|}
\hline & \\
\hline & \multicolumn{9}{|c|}{ Labor } \\
\hline & $\begin{array}{c}\text { Child } \\
\text { (age } 10 \text { to } \\
14 \text { ) }\end{array}$ & $\begin{array}{c}\text { Female } \\
\text { (no formal } \\
\text { education) }\end{array}$ & $\begin{array}{l}\text { Female } \\
\text { (not } \\
\text { finished } \\
\text { primary } \\
\text { school) }\end{array}$ & $\begin{array}{c}\text { Female } \\
\text { (not } \\
\text { finished } \\
\text { secondary } \\
\text { school) } \\
\end{array}$ & $\begin{array}{c}\text { Female } \\
\text { (secondary } \\
\text { or higher } \\
\text { education) }\end{array}$ & $\begin{array}{c}\text { Male } \\
\text { (no formal } \\
\text { education) }\end{array}$ & 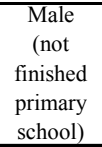 & $\begin{array}{c}\text { Male } \\
\text { (not } \\
\text { finished } \\
\text { secondary } \\
\text { school) } \\
\end{array}$ & $\begin{array}{c}\text { Male } \\
\text { (secondary } \\
\text { or higher } \\
\text { education) }\end{array}$ \\
\hline IRTS Goods and Services & 2.8 & -5.3 & 10.8 & -2.5 & 6.9 & 3.0 & 5.1 & 2.5 & 8.5 \\
\hline CRTS Goods and Services & -0.1 & 0.2 & -0.4 & 0.2 & -1.7 & -0.2 & -0.4 & -0.7 & -2.0 \\
\hline Business Services & 33.8 & 32.7 & 43.4 & 27.9 & 26.5 & 26.5 & 32.2 & 25.0 & 21.0 \\
\hline Telecommunication & & & & 3.3 & 5.1 & 3.5 & 5.9 & 3.8 & 3.9 \\
\hline Insurance & 35.7 & 34.6 & 45.4 & 35.3 & 37.8 & 35.6 & 38.8 & 36.1 & 36.2 \\
\hline Banking & 42.9 & 41.7 & 53.1 & 42.5 & 45.1 & 42.8 & 46.2 & 43.3 & 43.4 \\
\hline Professional business services & 25.6 & 24.6 & 34.5 & 25.2 & 27.5 & 25.5 & 28.5 & 25.9 & 26.1 \\
\hline Air transport & & & & 16.9 & 19.0 & 17.1 & 19.9 & 17.6 & 17.7 \\
\hline Road transport & & & & 20.0 & 22.1 & 20.2 & 23.0 & 20.6 & 20.7 \\
\hline Railway transport & & & & 19.9 & 22.0 & 20.1 & 23.0 & 20.5 & 20.7 \\
\hline Water transport & & & & 5.7 & 7.6 & 5.9 & 8.4 & 6.3 & 6.4 \\
\hline Dixit-Stiglitz Goods & -11.2 & -10.0 & -4.0 & -11.0 & -5.2 & -6.3 & -6.9 & -7.0 & -6.1 \\
\hline Processed food & & 0.9 & 9.0 & 1.5 & 3.3 & 1.7 & 4.1 & 2.0 & 2.1 \\
\hline Beverages \& tobacco products & & & & -6.3 & -4.6 & & -3.9 & -5.8 & -5.7 \\
\hline Textile \& leather products & -11.4 & -12.1 & -5.0 & -11.6 & -10.0 & -11.4 & -9.3 & -11.1 & -11.0 \\
\hline Wood paper printing & -7.3 & -8.1 & & -7.6 & -5.9 & -7.4 & -5.2 & -7.1 & -7.0 \\
\hline Manufacture of basic \& industrial chemicals & & & & & & & & -2.4 & \\
\hline Manufacture of fertilizers \& pesticides & & & & & & & & -0.3 & \\
\hline Petroleum refineries & & & & & & & & 0.0 & 0.1 \\
\hline Rubber plastic \& other manufacturing & & & & -4.8 & -3.0 & & -2.3 & -4.2 & -4.1 \\
\hline Glass \& cement & & -5.4 & 2.2 & -4.9 & & -4.7 & -2.4 & -4.3 & -4.3 \\
\hline Iron steel \& metal products & & & & & -1.6 & -3.2 & -0.9 & -2.9 & -2.8 \\
\hline Manufacture of equipment & & & & -5.3 & -3.6 & & -2.9 & -4.8 & -4.7 \\
\hline Agriculture & -0.1 & -0.2 & -2.0 & 0.1 & 2.6 & -0.3 & -1.7 & -1.2 & 0.3 \\
\hline Maize & 2.2 & 1.3 & 9.4 & 1.9 & 3.7 & 2.1 & 4.5 & 2.4 & 2.5 \\
\hline Paddy & -3.5 & -4.3 & 3.4 & -3.8 & -2.0 & -3.6 & -1.3 & -3.2 & -3.1 \\
\hline Sorghum or millets & 1.6 & 0.8 & 8.8 & 1.3 & & 1.5 & 3.9 & 1.9 & 2.0 \\
\hline Wheat & & & & & & & & -7.0 & \\
\hline Beans & & 1.4 & 9.6 & 2.0 & 3.8 & 2.2 & 4.6 & 2.6 & 2.7 \\
\hline Cassava & 1.6 & 0.8 & 8.9 & 1.4 & 3.2 & 1.5 & 4.0 & 1.9 & 2.0 \\
\hline Other cereals & 2.1 & 1.3 & 9.4 & 1.8 & 3.7 & 2.0 & 4.5 & 2.4 & 2.5 \\
\hline Oil seeds & 2.0 & 1.2 & 9.3 & 1.8 & & 2.0 & 4.4 & 2.3 & 2.4 \\
\hline Other roots \& tubes & 2.4 & 1.6 & 9.7 & 2.2 & & & 4.8 & 2.7 & 2.8 \\
\hline Cotton & -8.3 & -9.0 & -1.7 & -8.5 & & -8.3 & -6.1 & -8.0 & -7.9 \\
\hline Coffee & & -14.7 & -7.8 & -14.2 & & -14.0 & -12.0 & -13.7 & -13.6 \\
\hline Tobacco & & 4.1 & 12.5 & 4.7 & 6.6 & 4.9 & 7.4 & 5.3 & 5.4 \\
\hline Tea & & & & & & & -3.2 & & \\
\hline Cashew nuts & -4.9 & -5.6 & 1.9 & -5.1 & & -4.9 & -2.7 & -4.6 & \\
\hline Sisal fiber & & -12.2 & & & & -11.5 & -9.4 & -11.2 & -11.1 \\
\hline Sugar & & & -12.3 & & & & -16.3 & & \\
\hline Fruits \& vegetables & 1.2 & 0.4 & 8.5 & 1.0 & 2.8 & 1.2 & 3.6 & 1.5 & 1.6 \\
\hline Other crops & 3.3 & 2.5 & & 3.0 & 4.9 & 3.2 & 5.7 & 3.6 & 3.7 \\
\hline Poultry \& livestock & 1.1 & 0.3 & 8.3 & 0.8 & 2.6 & 1.0 & 3.4 & 1.4 & 1.5 \\
\hline Other CRTS & -0.3 & 2.4 & 11.9 & 0.7 & -1.8 & 0.1 & 2.0 & -0.4 & -2.1 \\
\hline Fish & & -0.1 & & 0.4 & & 0.6 & 3.0 & 1.0 & \\
\hline Hunting \& forestry & & & & 0.6 & & 0.8 & & 1.1 & 1.2 \\
\hline Mining \& quarrying & 0.4 & -0.4 & 7.5 & 0.1 & 1.9 & & 2.7 & 0.7 & 0.8 \\
\hline Meat \& dairy products & & & & 0.9 & 2.7 & 1.1 & 3.5 & 1.5 & 1.6 \\
\hline Grain milling & 1.3 & 0.4 & 8.5 & 1.0 & & 1.2 & 3.6 & 1.5 & 1.6 \\
\hline Utilities & & & & -1.4 & 0.4 & -1.2 & 1.2 & -0.8 & -0.7 \\
\hline Construction & -1.4 & -2.2 & & -1.7 & 0.1 & -1.5 & 0.8 & -1.2 & -1.1 \\
\hline Wholesale \& retail trade & -2.8 & -3.6 & 4.1 & -3.1 & -1.3 & -2.9 & -0.6 & -2.5 & -2.4 \\
\hline Hotels \& restaurants & 14.7 & 13.8 & 22.9 & 14.4 & 16.5 & 14.6 & 17.3 & 15.0 & 15.1 \\
\hline Postal communication & & & & -3.8 & -2.0 & -3.6 & -1.3 & -3.2 & -3.1 \\
\hline Real estate & & & & 2.9 & 4.7 & & 5.5 & 3.4 & 3.5 \\
\hline Other services & -1.3 & -2.1 & 5.8 & -1.5 & 0.2 & -1.3 & 1.0 & -1.0 & -0.9 \\
\hline Tourism & & & & & & & & & \\
\hline Public administration health \& education & & -4.6 & 3.0 & -4.1 & -2.4 & -3.9 & -1.6 & -3.6 & -3.5 \\
\hline
\end{tabular}

Source: Authors' estimates. 
Table 7 Impact on prices (\%-change from initial equilibrium)

\begin{tabular}{|c|c|c|c|c|c|c|c|}
\hline & Full Reform & $\begin{array}{c}\text { All services } \\
\text { barriers }\end{array}$ & $\begin{array}{c}\text { Only non- } \\
\text { discrimina- } \\
\text { tory services } \\
\text { barriers } \\
\end{array}$ & $\begin{array}{c}\text { Only } \\
\text { barriers } \\
\text { against FDI } \\
\text { in services } \\
\end{array}$ & $\begin{array}{c}\text { Only } \\
\text { uniform } \\
\text { tariffs }\end{array}$ & CRTS & Steady State \\
\hline IRTS Goods and Services & -6.5 & -6.5 & -5.1 & -1.1 & 0.3 & -2.2 & -12.8 \\
\hline CRTS Goods and Services & 2.3 & 1.7 & 1.3 & 0.3 & 0.4 & 0.8 & 4.3 \\
\hline Business Services & -24.6 & -25.1 & -19.1 & -5.4 & 0.6 & -11.8 & -30.2 \\
\hline Telecommunication & -11.3 & -12.2 & -6.4 & -5.1 & 0.9 & -3.4 & -16.6 \\
\hline Insurance & -23.9 & -24.7 & -13.5 & -9.6 & 0.9 & -8.7 & -28.8 \\
\hline Banking & -32.8 & -33.5 & -24.1 & -8.0 & 0.9 & -14.7 & -37.3 \\
\hline Professional business services & -13.7 & -14.6 & -9.2 & -4.3 & 0.9 & -3.9 & -19.0 \\
\hline Air transport & -17.0 & -17.1 & -15.2 & -1.3 & 0.1 & -6.3 & -24.8 \\
\hline Road transport & -22.6 & -22.6 & -20.7 & -1.4 & 0.1 & -9.9 & -29.9 \\
\hline Railway transport & -27.4 & -27.5 & -26.2 & -0.8 & 0.1 & -13.5 & -34.3 \\
\hline Water transport & -65.8 & -66.2 & -48.9 & -18.7 & 0.9 & -45.8 & -67.5 \\
\hline Dixit-Stiglitz Goods & -1.9 & -1.8 & -1.5 & -0.1 & 0.3 & 0.2 & -8.3 \\
\hline Processed food & -3.2 & -0.6 & -0.6 & 0.1 & -2.4 & -1.4 & -7.5 \\
\hline Beverages \& tobacco products & -3.1 & -1.4 & -0.8 & -0.2 & -1.6 & -0.8 & -8.0 \\
\hline Textile \& leather products & -4.7 & -0.5 & -0.3 & 0.0 & -3.9 & -2.1 & -8.6 \\
\hline Wood paper printing & -2.1 & -1.4 & -1.0 & -0.2 & -0.6 & -0.3 & -7.7 \\
\hline Manufacture of basic \& industrial chemicals & 0.3 & -3.5 & -3.1 & -0.2 & 4.3 & 2.4 & -5.9 \\
\hline Manufacture of fertilizers \& pesticides & 4.8 & 0.5 & 0.2 & 0.5 & 5.0 & 4.1 & -2.7 \\
\hline Petroleum refineries & 1.0 & -3.5 & -3.1 & -0.2 & 5.2 & 3.2 & -6.8 \\
\hline Rubber plastic \& other manufacturing & -1.2 & -2.9 & -2.4 & -0.2 & 2.0 & 1.2 & -10.1 \\
\hline Glass \& cement & 0.4 & -1.2 & -0.8 & -0.1 & 1.6 & 1.2 & -9.4 \\
\hline Iron steel \& metal products & -0.4 & -2.1 & -1.8 & -0.1 & 2.1 & 1.3 & -9.1 \\
\hline Manufacture of equipment & -1.1 & -2.6 & -2.4 & 0.0 & 2.0 & 1.0 & -9.8 \\
\hline Agriculture & 3.4 & 3.3 & 2.6 & 0.5 & 0.0 & 0.8 & 7.9 \\
\hline Maize & 4.9 & 3.9 & 3.0 & 0.6 & 0.8 & 1.9 & 13.4 \\
\hline Paddy & 1.4 & 2.1 & 1.6 & 0.4 & -0.7 & -0.4 & 4.0 \\
\hline Sorghum or millets & 3.0 & 2.4 & 2.0 & 0.4 & 0.3 & 0.9 & 9.6 \\
\hline Wheat & -0.2 & -0.4 & -0.5 & 0.2 & 0.3 & -0.2 & -2.3 \\
\hline Beans & 4.6 & 3.9 & 3.0 & 0.6 & 0.4 & 1.5 & 10.3 \\
\hline Cassava & 5.8 & 5.1 & 3.8 & 0.8 & 0.5 & 2.0 & 17.2 \\
\hline Other cereals & 3.8 & 2.8 & 2.1 & 0.4 & 0.9 & 1.5 & 5.9 \\
\hline Oil seeds & 4.5 & 3.8 & 2.9 & 0.6 & 0.5 & 1.5 & 9.4 \\
\hline Other roots \& tubes & 5.4 & 4.7 & 3.5 & 0.7 & 0.4 & 1.8 & 14.1 \\
\hline Cotton & 2.1 & 1.1 & 1.3 & 0.0 & 0.8 & 0.8 & -1.3 \\
\hline Coffee & 20.5 & 18.1 & 16.2 & 1.8 & 2.5 & 9.7 & 23.2 \\
\hline Tobacco & 1.1 & -0.2 & 0.8 & -0.5 & 1.2 & 0.1 & -1.4 \\
\hline Tea & 5.5 & 3.8 & 3.6 & 0.2 & 1.6 & 2.2 & 2.3 \\
\hline Cashew nuts & 21.7 & 20.1 & 17.4 & 2.5 & 1.2 & 9.8 & 26.6 \\
\hline Sisal fiber & 1.4 & 0.1 & 0.1 & 0.1 & 1.1 & 0.6 & -0.8 \\
\hline Sugar & -4.5 & 0.4 & 0.2 & 0.2 & -4.5 & -5.0 & -5.8 \\
\hline Fruits \& vegetables & 4.9 & 4.1 & 3.1 & 0.6 & 0.5 & 1.7 & 11.1 \\
\hline Other crops & 5.2 & 4.2 & 3.3 & 0.6 & 0.7 & 1.9 & 12.2 \\
\hline Poultry \& livestock & 4.1 & 3.3 & 2.5 & 0.5 & 0.6 & 1.4 & 8.8 \\
\hline Other CRTS & 2.0 & 1.2 & 1.0 & 0.3 & 0.6 & 0.8 & 3.4 \\
\hline Fish & 5.2 & 4.3 & 3.3 & 0.6 & 0.6 & 1.8 & 9.1 \\
\hline Hunting \& forestry & 4.5 & 3.8 & 2.9 & 0.6 & 0.5 & 1.6 & 13.4 \\
\hline Mining \& quarrying & 4.5 & 2.6 & 2.1 & 0.4 & 1.5 & 2.2 & -7.1 \\
\hline Meat $\&$ dairy products & 4.2 & 3.8 & 2.9 & 0.6 & 0.2 & 1.3 & 10.2 \\
\hline Grain milling & 2.6 & 2.3 & 1.8 & 0.4 & 0.1 & 0.6 & 6.2 \\
\hline Utilities & 1.2 & -0.2 & 0.0 & 0.1 & 1.2 & 0.7 & -5.8 \\
\hline Construction & 1.4 & 0.4 & 0.3 & 0.2 & 0.9 & 0.8 & -0.4 \\
\hline Wholesale \& retail trade & 0.5 & -0.7 & -0.2 & -0.1 & 0.9 & 0.1 & -8.4 \\
\hline Hotels \& restaurants & 2.1 & 1.1 & 1.0 & 0.2 & 0.7 & 0.8 & -3.1 \\
\hline Postal communication & -2.3 & -3.2 & -2.2 & -0.5 & 0.8 & -0.9 & -6.7 \\
\hline Real estate & 2.6 & 1.7 & 1.5 & 0.3 & 0.7 & 1.1 & 7.9 \\
\hline Other services & -0.6 & -1.6 & -0.9 & -0.3 & 0.8 & -0.2 & -5.4 \\
\hline Tourism & -1.6 & -2.4 & -2.3 & 0.1 & 0.6 & -0.7 & -4.9 \\
\hline Public administration health $\&$ education & 0.9 & 0.4 & 0.3 & 0.3 & 0.3 & 0.4 & 6.2 \\
\hline
\end{tabular}

Source: Authors' estimates. 
Table 8. Impact on sectoral activity (\%-change from initial equilibrium)

\begin{tabular}{|c|c|c|c|c|c|c|c|}
\hline & Full Reform & $\begin{array}{c}\text { All services } \\
\text { barriers }\end{array}$ & $\begin{array}{l}\text { Only non- } \\
\text { discrimina- } \\
\text { tory services } \\
\text { barriers } \\
\end{array}$ & $\begin{array}{c}\text { Only } \\
\text { barriers } \\
\text { against FDI } \\
\text { in services }\end{array}$ & $\begin{array}{c}\text { Only } \\
\text { uniform } \\
\text { tariffs }\end{array}$ & CRTS & Steady State \\
\hline IRTS Goods and Services & 11.4 & 12.8 & 8.3 & 3.1 & -1.1 & 5.8 & 30.1 \\
\hline CRTS Goods and Services & 7.0 & 5.0 & 4.5 & 0.2 & 1.2 & 2.8 & 20.8 \\
\hline Business Services & 37.5 & 36.2 & 24.4 & 8.4 & 0.8 & 16.1 & 67.4 \\
\hline Telecommunication & 21.7 & 22.2 & 13.4 & 5.7 & -0.6 & 7.7 & 43.6 \\
\hline Insurance & 51.2 & 52.6 & 27.7 & 17.8 & -1.0 & 20.1 & 79.9 \\
\hline Banking & 59.2 & 60.6 & 38.8 & 15.8 & -1.0 & 27.4 & 88.4 \\
\hline Professional business services & 39.9 & 41.4 & 22.1 & 11.8 & -1.0 & 13.5 & 67.6 \\
\hline Air transport & 31.6 & 25.8 & 20.9 & 2.7 & 4.2 & 13.8 & 69.7 \\
\hline Road transport & 35.1 & 29.0 & 24.2 & 2.8 & 4.2 & 16.3 & 73.8 \\
\hline Railway transport & 35.0 & 29.0 & 24.5 & 2.5 & 4.2 & 17.1 & 72.6 \\
\hline Water transport & 24.5 & 25.0 & 21.7 & 9.7 & -0.6 & 13.9 & 44.9 \\
\hline Dixit-Stiglitz Goods & -0.9 & 1.9 & 0.8 & 0.6 & -2.0 & 0.9 & 12.6 \\
\hline Processed food & 4.8 & 2.7 & 1.9 & 0.5 & 2.1 & 3.8 & 15.5 \\
\hline Beverages \& tobacco products & 0.1 & 5.0 & 3.4 & 0.9 & -4.4 & 0.8 & 11.6 \\
\hline Textile \& leather products & -8.9 & 1.6 & 0.7 & 0.5 & -9.3 & -2.3 & -2.2 \\
\hline Wood paper printing & -4.2 & 1.1 & -0.7 & 1.2 & -4.1 & 0.0 & 4.6 \\
\hline Manufacture of basic \& industrial chemicals & 5.8 & 4.9 & 3.1 & 1.1 & 1.6 & 1.7 & 11.8 \\
\hline Manufacture of fertilizers \& pesticides & 0.5 & -10.0 & -8.6 & -1.6 & 9.9 & 2.8 & 13.1 \\
\hline Petroleum refineries & 6.5 & 0.4 & -1.5 & 1.1 & 7.9 & 4.4 & 30.2 \\
\hline Rubber plastic \& other manufacturing & 2.9 & 2.6 & 0.8 & 1.1 & 1.2 & 1.7 & 28.1 \\
\hline Glass \& cement & 0.9 & 1.3 & 0.6 & 0.4 & -0.3 & 0.8 & 20.6 \\
\hline Iron steel \& metal products & 1.3 & -0.2 & -1.1 & 0.5 & 2.5 & 1.4 & 22.6 \\
\hline Manufacture of equipment & -2.0 & -2.0 & -2.9 & 0.6 & 1.2 & 0.2 & 38.3 \\
\hline Agriculture & -1.0 & -0.8 & -0.7 & -0.4 & -0.1 & -1.0 & 6.3 \\
\hline Maize & 1.6 & 1.1 & 0.8 & 0.2 & 0.5 & 1.0 & 4.5 \\
\hline Paddy & -2.4 & 1.3 & 0.9 & 0.3 & -2.9 & -2.5 & 0.7 \\
\hline Sorghum or millets & 2.8 & 2.6 & 2.0 & 0.4 & 0.1 & 1.2 & 8.6 \\
\hline Wheat & -5.7 & -3.3 & -3.2 & 0.0 & -1.4 & -2.9 & -8.7 \\
\hline Beans & 2.2 & 2.1 & 1.6 & 0.3 & 0.1 & 0.9 & 9.0 \\
\hline Cassava & 0.3 & 0.4 & 0.3 & 0.0 & 0.0 & 0.1 & 1.2 \\
\hline Other cereals & 2.3 & 2.7 & 1.9 & 0.4 & -0.3 & 1.1 & 9.9 \\
\hline Oil seeds & 2.0 & 1.5 & 1.1 & 0.3 & 0.5 & 1.1 & 9.2 \\
\hline Other roots \& tubes & 1.6 & 1.5 & 1.2 & 0.2 & 0.1 & 0.7 & 6.1 \\
\hline Cotton & -4.1 & 1.6 & 1.0 & 0.4 & -6.3 & -0.4 & 11.1 \\
\hline Coffee & -13.1 & -23.8 & -19.5 & -7.0 & 8.3 & -9.3 & 9.6 \\
\hline Tobacco & 12.5 & 10.0 & 6.8 & 1.9 & 0.4 & 7.1 & 38.7 \\
\hline Tea & -2.4 & -4.1 & -3.9 & -0.1 & -0.6 & -1.6 & 20.9 \\
\hline Cashew nuts & -4.5 & -20.0 & -13.7 & -9.2 & 17.4 & -3.2 & 19.0 \\
\hline Sisal fiber & -8.9 & 1.6 & 0.7 & 0.5 & -9.3 & -2.3 & -2.2 \\
\hline Sugar & -14.9 & -3.1 & -3.0 & 0.1 & -10.4 & -11.3 & -15.5 \\
\hline Fruits \& vegetables & 0.8 & 0.6 & 0.5 & 0.1 & 0.2 & 0.4 & 5.3 \\
\hline Other crops & 3.0 & 2.2 & 1.9 & 0.2 & 0.5 & 1.3 & 10.5 \\
\hline Poultry \& livestock & 1.6 & 1.4 & 1.1 & 0.1 & 0.2 & 0.5 & 8.4 \\
\hline Other CRTS & 4.0 & 3.6 & 2.6 & 0.6 & 0.3 & 1.7 & 14.7 \\
\hline Fish & 0.8 & -0.4 & -0.1 & -0.2 & 0.9 & 0.3 & 8.9 \\
\hline Hunting \& forestry & 1.1 & 1.5 & 1.0 & 0.3 & -0.3 & 0.5 & 4.9 \\
\hline Mining \& quarrying & 0.8 & -2.2 & -2.3 & 0.0 & 3.1 & 1.7 & 31.1 \\
\hline Meat \& dairy products & -0.1 & 1.2 & 0.9 & 0.2 & -1.1 & -0.6 & 3.8 \\
\hline Grain milling & 3.1 & 2.8 & 2.1 & 0.4 & 0.2 & 1.4 & 10.3 \\
\hline Utilities & 3.1 & 5.0 & 3.3 & 1.1 & -1.6 & 1.6 & 20.3 \\
\hline Construction & 1.9 & 2.0 & 1.4 & 0.4 & -0.1 & 0.8 & 23.5 \\
\hline Wholesale \& retail trade & 2.6 & 2.6 & 1.7 & 0.5 & -0.1 & 1.2 & 18.4 \\
\hline Hotels \& restaurants & 18.2 & 13.7 & 12.0 & 1.1 & 2.8 & 7.6 & 44.5 \\
\hline Postal communication & 8.6 & 9.2 & 5.2 & 2.4 & -0.5 & 3.4 & 28.9 \\
\hline Real estate & 6.7 & 6.7 & 4.7 & 1.3 & -0.1 & 2.5 & 16.7 \\
\hline Other services & 6.5 & 7.6 & 1.9 & 3.7 & -0.8 & 2.4 & 29.2 \\
\hline Tourism & 81.5 & 49.7 & 52.0 & -1.6 & 19.9 & 34.6 & 164.6 \\
\hline Public administration health \& education & 0.9 & 0.7 & 0.2 & 0.2 & 0.2 & 0.3 & 0.1 \\
\hline
\end{tabular}

Source: Authors' estimates. 
Table 9. Piecemeal sensitivity analysis - welfare effects

\begin{tabular}{|c|c|c|c|c|c|c|}
\hline \multirow[b]{2}{*}{ Parameter $^{\mathrm{a}}$} & \multicolumn{3}{|c|}{ Parameter value } & \multicolumn{3}{|c|}{$\begin{array}{l}\text { Hicksian equivalent variation }{ }^{\mathrm{b}} \\
\text { with corresponding parameter }\end{array}$} \\
\hline & Lower & Central & Upper & Lower & Central & Upper \\
\hline$\sigma(\mathrm{va}, \mathrm{bs})$ & 0.5 & 1.25 & 2 & 4.0 & 5.3 & 8.5 \\
\hline$\sigma\left(\mathrm{q}_{\mathrm{i}}, \mathrm{q}_{\mathrm{j}}\right)$ & 2 & 3 & 4 & 14.5 & 5.3 & 3.8 \\
\hline$\sigma(\mathrm{D}, \mathrm{M})$ & 2 & 4 & 6 & 4.6 & 5.3 & 5.9 \\
\hline$\sigma(\mathrm{L}, \mathrm{K})$ & 0.7 & 1 & 1.3 & 5.3 & 5.3 & 5.3 \\
\hline$\sigma\left(\mathrm{A}_{1}, \ldots \mathrm{A}_{\mathrm{n}}\right)$ & 0 & 0 & 0.25 & 5.3 & 5.3 & 5.4 \\
\hline$\sigma(\mathrm{D}, \mathrm{E})$ & 2 & 4 & 6 & 5.1 & 5.3 & 5.6 \\
\hline$\varepsilon\left(\mathrm{d}_{\mathrm{i}}\right)$ & 2 & 4 & 6 & 4.9 & 5.3 & 5.6 \\
\hline$\varepsilon\left(\mathrm{f}_{\mathrm{i}}\right)$ & 2 & 4 & 6 & 3.6 & 5.3 & 6.7 \\
\hline$\theta \mathrm{m}(\mathrm{i})$ & \multicolumn{3}{|c|}{ see table below } & 5.3 & 5.3 & 5.3 \\
\hline$\theta$ fdi(i) & \multicolumn{3}{|c|}{ see table below } & 5.1 & 5.3 & 5.6 \\
\hline
\end{tabular}

${ }^{a}$ The piecemeal sensitivity analysis employs central values for all parameters other than the tested parameter and lump sum tax replacement.

${ }^{b}$ Hicksian equivalent variation as a percent of the value of consumption in the benchmark equilibrium.

Key:

\begin{tabular}{|c|c|c|c|c|c|c|c|}
\hline Parameter & \multicolumn{7}{|c|}{ Definition of the parameter } \\
\hline$\sigma(\mathrm{va}, \mathrm{bs})$ & \multicolumn{7}{|c|}{ Elasticity of substitution between value-added and business services } \\
\hline$\sigma\left(\mathrm{q}_{\mathrm{i}}, \mathrm{q}_{\mathrm{j}}\right)$ & \multicolumn{7}{|c|}{ Elasticity of substitution between firm varieties in imperfectly competitive sectors } \\
\hline$\sigma(\mathrm{D}, \mathrm{M})$ & \multicolumn{7}{|c|}{ "Armington" elasticity of substitution between imports and domestic goods in CRTS sectors } \\
\hline$\sigma(\mathrm{L}, \mathrm{K})$ & \multicolumn{7}{|c|}{ Elasticity of substitution between primary factors of production in value added } \\
\hline$\sigma\left(\mathrm{A}_{1}, \ldots \mathrm{A}_{\mathrm{n}}\right)$ & \multicolumn{7}{|c|}{ Elasticity of substitution in intermediate production between composite Armington aggregate goods } \\
\hline$\sigma(\mathrm{D}, \mathrm{E})$ & \multicolumn{7}{|c|}{ Elasticity of transformation (domestic output versus exports) } \\
\hline$\varepsilon\left(\mathrm{d}_{\mathrm{i}}\right)$ & \multicolumn{7}{|c|}{ Elasticity of national service firm supply with respect to price of output } \\
\hline$\varepsilon\left(\mathrm{f}_{\mathrm{i}}\right)$ & \multicolumn{7}{|c|}{ Elasticity of multinational service firm supply with respect to price of output } \\
\hline$\theta \mathrm{m}(\mathrm{i})$ & \multicolumn{7}{|c|}{$\begin{array}{l}\text { Share of value added in multinational firms in sector I due to specialized primary factor imports, in } \\
\text { the benchmark equilibrium }\end{array}$} \\
\hline \multirow[t]{11}{*}{$\theta$ fdi(i) } & \multicolumn{7}{|c|}{ Share of output of service sector I captured by multinationals firms in the benchmark equilibrium } \\
\hline & \multirow[t]{2}{*}{ Parameter values for: } & \multicolumn{3}{|c|}{$\theta$ fdi(i) } & \multicolumn{3}{|c|}{$\theta \mathrm{m}(\mathrm{i})$} \\
\hline & & Lower & Central & Upper & Lower & Central & Upper \\
\hline & Telecommunication & 0.85 & 0.9 & 0.95 & 0.025 & 0.05 & 0.1 \\
\hline & Insurance & 0.2 & 0.3 & 0.4 & 0.025 & 0.05 & 0.1 \\
\hline & $\begin{array}{l}\text { Banking } \\
\text { Profession }\end{array}$ & 0.3 & 0.4 & 0.5 & 0.025 & 0.05 & 0.1 \\
\hline & services & 0.2 & 0.3 & 0.4 & 0.025 & 0.05 & 0.1 \\
\hline & Road transport & 0.1 & 0.2 & 0.3 & 0.025 & 0.05 & 0.1 \\
\hline & Railway transport & 0.5 & 0.6 & 0.7 & 0.025 & 0.05 & 0.1 \\
\hline & Water transport & 0.7 & 0.8 & 0.9 & 0.025 & 0.05 & 0.1 \\
\hline & Air transport & 0.3 & 0.4 & 0.5 & 0.025 & 0.05 & 0.1 \\
\hline
\end{tabular}


Figure 1: Production and Allocation of Output

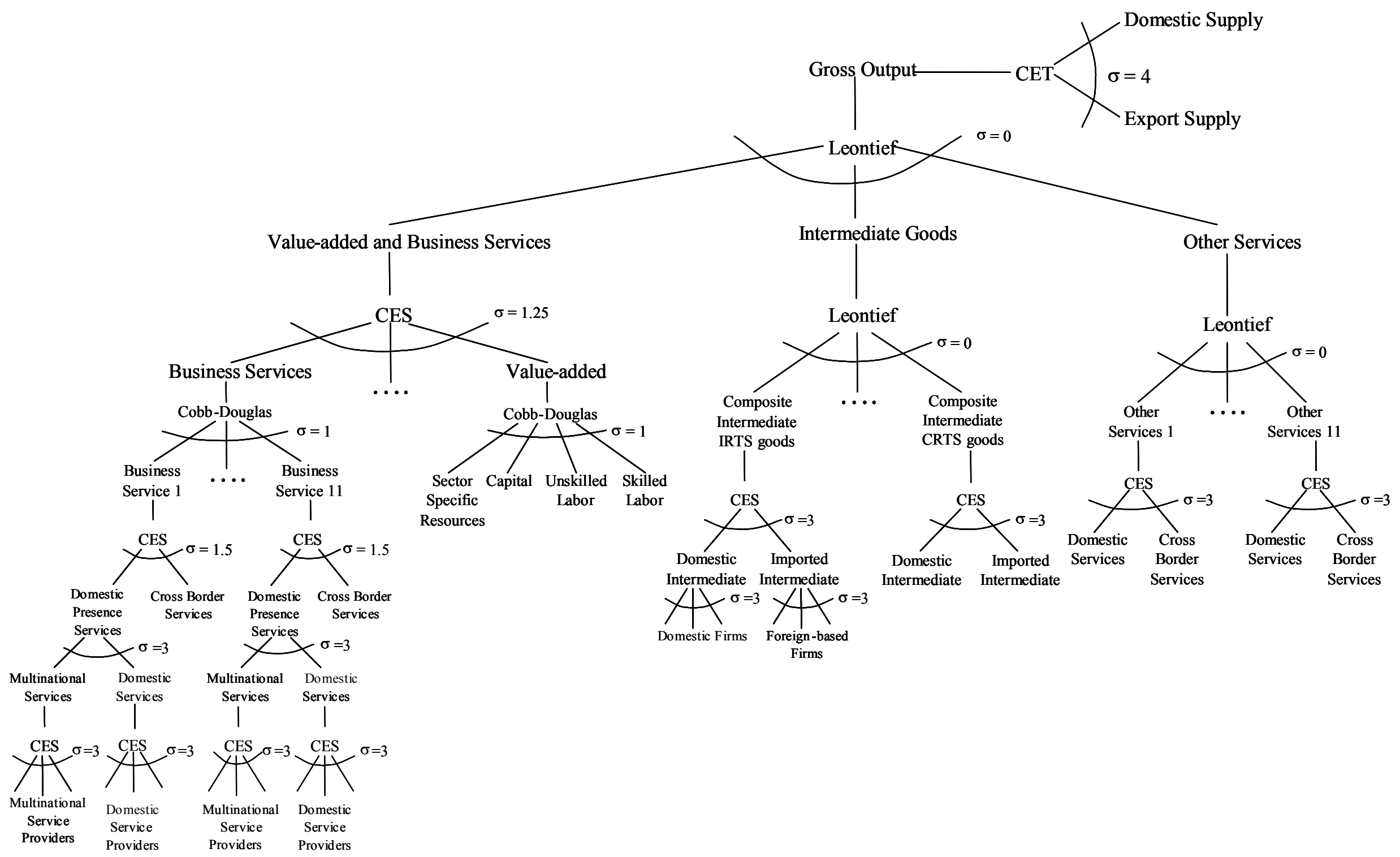

